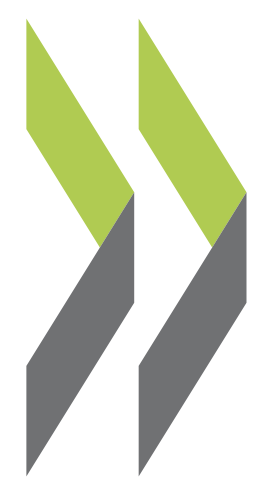

OECD Working Papers on International Investment 2006/02

\title{
Investor-to-State Dispute
} Settlement in Infrastructure

\section{Catriona Paterson}

Projects 


\title{
OECD $\ll \bigcirc$ OCDE
}

\author{
WORKING PAPERS ON INTERNATIONAL INVESTMENT
}

Number 2006/2

\section{INVESTOR-TO-STATE DISPUTE SETTLEMENT IN INFRASTRUCTURE PROJECTS}

March 2006

This paper was prepared in the context of the Investment Committee's project on International Investor Participation in Infrastructure. It summarises information available in the public domain about investor-state dispute settlements in the infrastructure sectors. The document as a factual survey, however, does not necessarily reflect the views of the OECD or those of its Member governments. It cannot be construed as prejudging ongoing or future negotiations or disputes pertaining to international investment agreements .

The purpose of the paper is to provide an indication of some of the challenges to international investor participation in infrastructure that have in the past led to the breakdown of working relationships between public and private partners. This paper was prepared by Catriona Paterson, a Consultant in the OECD Investment Division. 


\section{TABLE OF CONTENTS}

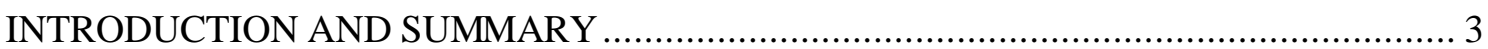

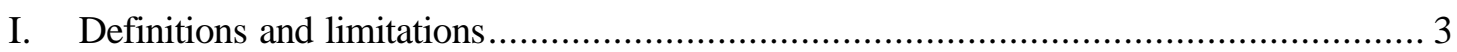

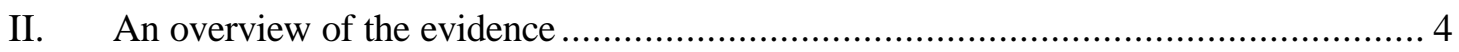

1) The nature of the disputes: sectoral and other characteristics.............................13

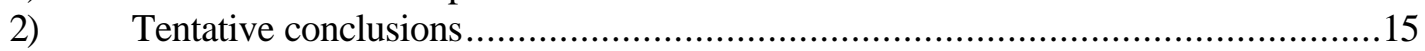

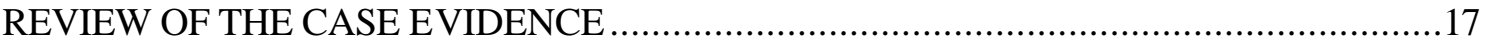

I. Arbitrations and settlement agreements in infrastructure projects ..............................17

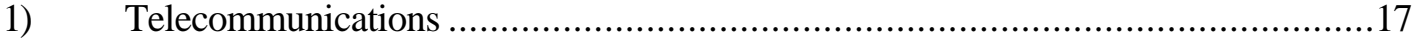

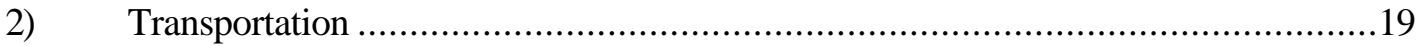

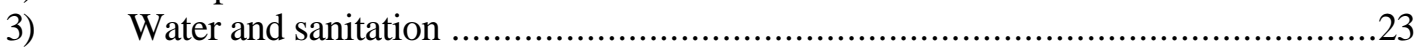

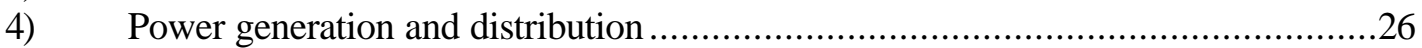

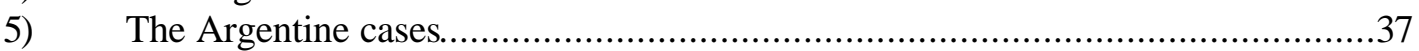

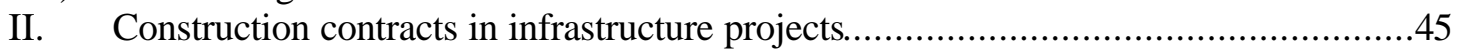




\section{INTRODUCTION AND SUMMARY}

1. This paper was prepared in the context of the Investment Committee's project on International Investor Participation in Infrastructure, as agreed by the Committee at its meeting in September 2005. It summarises information available in the public domain about investor-state dispute settlements in the infrastructure sectors. The main purpose of the paper is to provide a rough indication of some of the challenges to international investor participation in infrastructure that have in the past led to the breakdown of working relationships between the public and private partners.

\section{Definitions and limitations}

2. It should be first noted that arbitrational proceedings represent, at most, only one aspect of dealing with disputes in this area. Many disputes are of a purely contractual nature, and are dealt with by the national courts. Moreover, it would appear that most investor-state disputes are settled privately or lead to renegotiations of the relevant infrastructure contracts. Some of these negotiations have taken place amid considerable acrimony, which indicates that the parties to infrastructure contracts are often willing to go a long way to avoid the lengthy and costly court and arbitration procedures.'

3. Secondly, reliance on information that is in the public domain imposes additional restrictions. In a number of cases, there is no complete information on settlement agreements or on whether the arbitral process has produced a final award. The reasons for this lack of information may be various but may in part arise from confidentiality concerns. A main perceived advantage of commercial arbitration is confidentiality and the corresponding protection of sometimes commercially sensitive information. In contrast, arguments in favour of confidentiality in arbitrations involving States are sometimes considered less persuasive as the existence of public interest issues argues in favour of transparency. Recent trends in arbitral practice indicate a greater willingness to make arbitration awards publicly available. Awards rendered under the Convention on the Settlement of Investment Disputes between States and Nationals of Other States 1965 (ICSID) are generally made publicly available. In contrast, other arbitral institutions, particularly those that were originally conceived for private commercial arbitration, do not provide for the same degree of access to information. This may a lso affect availability of information regarding the number of arbitrations being conducted by different arbitral institutions or under various arbitration rules.

4. Lastly, while it may seem from Table 1 that the preponderance of disputes arise in the energy sector, this does not necessarily reflect the proportionate number of disputes arising in each industry sector. Rather, as this study is not intended to be comprehensive and as energy is an area of high public interest, this preponderance of cases may simply reflect availability of information. Also included in the study are the three cases under Energy Charter Treaty which have arisen to date. While not all three

1. For a comprehensive overview see J. L. Guasch (2004), Granting and Renegotiating Infrastructure Concessions: Doing it Right, World Bank Institute Development Studies. 
cases fall within the definition of infrastructure as understood in this study, they are included because of the importance of the Treaty in infrastructure projects in the energy sector.

\section{An overview of the evidence}

5. This study has canvassed 28 arbitrations and settlement agreements in infrastructure projects involving telecommunications, transportation, water and sanitation and the energy sector. Included in this study are both final awards and decisions on jurisdiction rendered by arbitral tribunals as both types of awards may elucidate the underlying nature of the dispute and assist with the analysis. Tables 1 and 2 provide information arising out of arbitrations or negotiated settlements relating to infrastructure projects and from which certain parallels may be drawn between disputes arising in infrastructure projects. The cases included in Table 1 relate to disputes that have arisen in the course of infrastructure service contracts or concessions. Table 2 summarises disputes that have arisen in the context of the construction infrastructure. More detailed information on each case is provided in the Annex.

6. Parallels may be drawn between disputes arising in infrastructure projects relating to the jurisdictional basis for raising a claim in the international sphere, the nature of the agreement underlying the investor's involvement in the project, whether the project in question was terminated or completed, the underlying factual issues giving rise to the dispute and the manner in which the dispute was finally resolved.

7. A point which may distinguish between infrastructure cases is the underlying agreement forming the relationship between the parties. More precisely, five projects proceeded on the basis of concession contracts, six proceeded on the basis of construction contracts and seven involved privatisation agreements entered into either with the investor or the enterprise in which the investor had a shareholding. The remaining cases involved a variety of contractual relationships or no contract between the parties. Whether a dispute can be taken to international arbitration is dependent on the parties' consent to arbitral jurisdiction. As can be seen from the tables, in the majority of arbitrations reviewed, consent to arbitration was contained in a BIT. Although consent to arbitration may also be contained in an investment contract, this appears to be the jurisdictional basis for arbitration in only a minority of cases. In none of the cases did jurisdiction arise from domestic investment legislation.

8. Other jurisdictional elements relate to jurisdiction ratione personae or the nature of the Claimant and jurisdiction ratione materiae or the subject matter of the claim. Whether a claim may be raised directly or indirectly by an investor or investment protection is extended to shareholders depends on the provisions of the investment protection instruments at issue in each particular case. In seventeen of the cases studied, the investor was directly involved in realisation of the project or participated in the project through subsidiary enterprises. In eight of the cases studied, the claim raised was based on the disputed conduct affecting the claimant's shareholding in an enterprise involved in infrastructure projects. Five of these shareholder claims relate to disputes arising out of the Argentine financial crisis. ${ }^{2}$ Two of the disputes have been rejected by arbitral tribunals on the grounds of non-fulfilment of jurisdiction ratione materiae. All four of the settlement agreements appear to have had an arguable basis to assert jurisdiction on the international plane.

2. Jurisdiction ratione personae has been denied by arbitral tribunals in two of the disputes examined in this study although in neither of these decisions did the jurisdictional question turn on the direct or indirect nature of the investment. 
9. A further point of comparison between the cases studied is the fate of the project following the dispute, i.e. whether the dispute led to termination of the project or whether it was completed or performance continued under the relevant contract. In ten cases, limited information was available to determine definitively at what point in the project the dispute arose or whether the project was terminated or continued. Of the remaining 18 cases, thirteen contracts or projects were terminated. In at least three of these cases the dispute arose prior to commencement of the project with the consequence that the investors did not undertake the infrastructure project in question.

10. In respect of eight cases where the project or contract was terminated, completion or performance of the project was ultimately assumed by the State or a third party. In three cases, limited information is available to determine whether the project was abandoned in its entirety or whether it was continued by another party. By contrast, in nine of the cases reviewed, the dispute did not cause the termination of the contract or the project. In four of these cases, all which relate to construction contracts, the dispute arose after performance under the relevant contract or completion of the project. In a further five cases the project continued despite the existence of a dispute between the parties.

11. Further comparisons may be drawn with respect to the manner in which the dispute was resolved. Of the twenty eight disputes examined in this study, four resulted in settlement agreements which finally resolved the dispute between the parties. At least two of these settlement agreements included pecuniary damages; the terms of settlement are unknown in respect of two other disputes. Settlement agreements were reached in a further two cases arising under construction contracts but did not settle all of the issues in dispute or reached interim agreements pending a final arbitral decision on the merits. One further settlement agreement granting pecuniary damages to the investor was entered into with a state agency; this agreement was found not to have prejudiced the investor's claim against the State itself, although jurisdiction was ultimately denied on other grounds. Ten of the disputes are currently still in the arbitral process, decisions on the merits are pending.

12. Final Decisions have been handed down in fifteen cases. Seven of these arbitral claims raised were rejected on the merits or refused on jurisdictional grounds. Eight awards resulted in pecuniary damages being awarded to the claimant investor. Of these eight awards, four also included a nonpecuniary element such as the CMS v Argentina $^{3}$ case where the Tribunal also ordered the respondent State to purchase the Claimant's shareholding within a specified time period and at a specified purchase price. Only one award, the TANESCO $O^{4}$ claim, is entirely non-pecuniary; in that award the Tribunal concluded on the contractual obligations extant between the parties and ordered to parties to comply with their contractual obligations.

3. CMS Gas Transmission Company v Argentina (ICSID Case No Arb/01/8), Decision on Jurisdiction 17 July, 2003.

4. Tanzania Electric Supply Company Limited (TANESCO) v Independent Power Tanzania Limited (IPTL), (ICSID Case No. ARB/98/8) Award 12 July 2001. 
Table 1. Arbitral decision \& negotiated settlements in cases related to infrastructure operations ${ }^{1}$

\begin{tabular}{|c|c|c|c|c|c|c|c|c|c|}
\hline 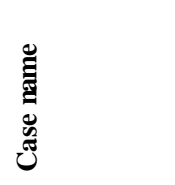 & 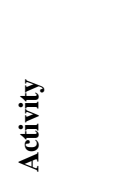 & 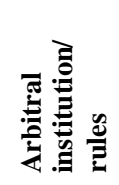 & 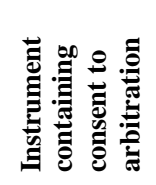 & 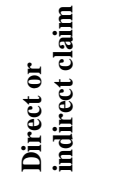 & 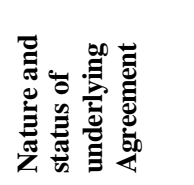 & 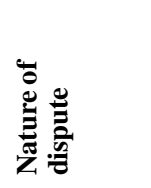 & 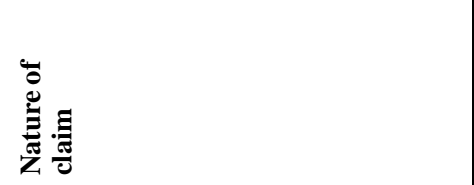 & 商 & 茪 \\
\hline \multicolumn{10}{|c|}{ Water sector: } \\
\hline $\begin{array}{l}\text { Aguas del } \\
\text { Tunari v } \\
\text { Bolivia, } \\
\text { Decision on } \\
\text { Jurisdiction, } \\
21 \text { Oct } 2005\end{array}$ & $\begin{array}{l}\text { Water } \\
\text { and } \\
\text { sewage } \\
\text { facilities }\end{array}$ & ICSID & $\begin{array}{l}\text { Netherlands } \\
\text { - Bolivia } \\
\text { BIT }\end{array}$ & $\begin{array}{l}\text { Indirect } \\
\text { claim }\end{array}$ & $\begin{array}{l}\text { Concession } \\
\text { agreement, } \\
\text { contract } \\
\text { rescinded. }\end{array}$ & $\begin{array}{l}\text { Policy } \\
\text { changes }\end{array}$ & $\begin{array}{l}\text { The dispute arose as public resistance } \\
\text { to the concession terms made the } \\
\text { Bolivian authorities rescind the } \\
\text { contract. Aguas del Tunari asserts the } \\
\text { authorities acted in breach of the } \\
\text { investor protection provisions of the } \\
\text { relevant BIT. }\end{array}$ & N/A & $\begin{array}{l}\text { A } \\
\text { Tribunal has assumed } \\
\text { jurisdiction to hear the claims. }\end{array}$ \\
\hline $\begin{array}{l}\text { The Biwater } \\
\text { Dispute, case } \\
\text { registered } \\
2 \text { Nov } 2005\end{array}$ & $\begin{array}{l}\text { Water } \\
\text { and } \\
\text { sewage } \\
\text { facilities }\end{array}$ & ICSID & $\mathrm{N}^{2} \mathrm{~A}^{2}$ & & $\begin{array}{l}\text { Privatisation } \\
\text { agreement; } \\
\text { contract } \\
\text { terminated }\end{array}$ & & $\begin{array}{l}\text { Both parties to this dispute have } \\
\text { alleged breach of contract; Biwater has } \\
\text { also stated it will contest the } \\
\text { legitimacy of the termination of } \\
\text { contract }\end{array}$ & N/A & $\begin{array}{l}\text { Dispute has been submitted to } \\
\text { international arbitration }\end{array}$ \\
\hline $\begin{array}{l}\text { Vivendi v } \\
\text { Argentina, } \\
\text { Award of } \\
21 \text { Nov } 2000\end{array}$ & $\begin{array}{l}\text { Water } \\
\text { distrib- } \\
\text { ution }\end{array}$ & ICSID & $\begin{array}{l}\text { France- } \\
\text { Argentina } \\
\text { BIT }\end{array}$ & $\begin{array}{l}\text { Direct } \\
\text { claim by } \\
\text { investor }\end{array}$ & $\begin{array}{l}\text { Concession } \\
\text { Contract; } \\
\text { contract } \\
\text { terminated }\end{array}$ & $\begin{array}{l}\text { Policy } \\
\text { change } \\
\text { (Provincial } \\
\text { authorities) }\end{array}$ & $\begin{array}{l}\text { Claimants alleged a series of contract } \\
\text { breaches and, under the BIT, violations } \\
\text { of the fair and equitable standard of } \\
\text { treatment and expropriation }\end{array}$ & Negotiations failed & $\begin{array}{l}1^{\text {st }} \text { Award annulled; new } \\
\text { decision pending }\end{array}$ \\
\hline \multicolumn{10}{|c|}{ Energy sector: } \\
\hline $\begin{array}{l}\text { OPIC } \\
\text { Decision, } \\
\text { Ponderosa } \\
\text { Assets S.A., } \\
\text { Decision } \\
2 \text { Aug 2005 }\end{array}$ & $\begin{array}{l}\text { Gas } \\
\text { transport }\end{array}$ & $\begin{array}{l}\text { OPIC } \\
\text { Tribunal }\end{array}$ & $\begin{array}{l}\text { OPIC } \\
\text { Contract } \\
\text { (US } \\
\text { investor; } \\
\text { US } \\
\text { overseas } \\
\text { investment } \\
\text { insurance } \\
\text { scheme) }\end{array}$ & $\begin{array}{l}\text { Indirect } \\
\text { claim by } \\
\text { share } \\
\text { holder }\end{array}$ & $\begin{array}{l}\text { Privatisation of } \\
\text { industry sector }\end{array}$ & $\begin{array}{l}\text { Policy } \\
\text { changes }\end{array}$ & $\begin{array}{l}\text { The dispute in this case relates to the } \\
\text { termination of US dollar based tariffs } \\
\text { and termination of certain tariff } \\
\text { adjustment mechanisms as part of the } \\
\text { foreign exchange reforms taken in an } \\
\text { attempt to remedy the Argentine } \\
\text { financial crisis; the Claimant alleged } \\
\text { breach of contract, breach of fair and } \\
\text { equitable treatment and expropriation } \\
\text { of investment }\end{array}$ & & $\begin{array}{l}\text { The OPIC Tribunal concluded } \\
\text { the acts of the Argentinean } \\
\text { government amounted to } \\
\text { expropriation as the value of the } \\
\text { investor's investment was } \\
\text { extinguished. As such, the } \\
\text { Claimant was entitled to claim } \\
\text { for damages under its political } \\
\text { risk insurance }\end{array}$ \\
\hline $\begin{array}{l}\text { CMS Gas } \\
\text { Transmission } \\
\text { v Argentina, } \\
\text { Award } \\
12 \text { May } 2005\end{array}$ & $\begin{array}{l}\text { Gas } \\
\text { trans- } \text { port }^{3}\end{array}$ & ICSID & $\begin{array}{l}\text { US- } \\
\text { Argentina } \\
\text { BIT }\end{array}$ & $\begin{array}{l}\text { Indirect } \\
\text { claim by } \\
\text { share } \\
\text { holder }\end{array}$ & $\begin{array}{l}\text { Privatisation of } \\
\text { industry sector }\end{array}$ & $\begin{array}{l}\text { Policy } \\
\text { changes }\end{array}$ & $\begin{array}{l}\text { The dispute in this case relates to the } \\
\text { termination of US dollar based tariffs } \\
\text { and termination of certain tariff } \\
\text { adjustment mechanisms as part of the } \\
\text { foreign exchange reforms taken in an } \\
\text { attempt to remedy the Argentine } \\
\text { financial crisis; the Claimant alleged } \\
\text { breach of contract, breach of fair and } \\
\text { equitable treatment and expropriation } \\
\text { of investment }\end{array}$ & & $\begin{array}{l}\text { The Tribunal rejected claims of } \\
\text { expropriation but held } \\
\text { Argentina liable for breach of } \\
\text { contract and breach of fair and } \\
\text { equitable treatment; the } \\
\text { Tribunal awarded pecuniary } \\
\text { damages and ordered Argentina } \\
\text { to re-purchase the Claimant's } \\
\text { shareholding. Argentina has } \\
\text { recently instituted annulment } \\
\text { proceedings against this } \\
\text { decision }\end{array}$ \\
\hline
\end{tabular}




\begin{tabular}{|c|c|c|c|c|c|c|c|c|c|}
\hline 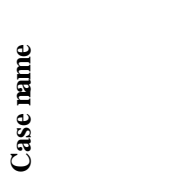 & 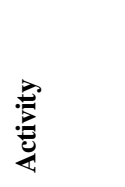 & 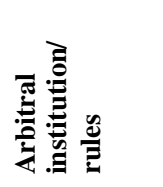 & 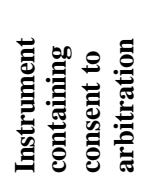 & 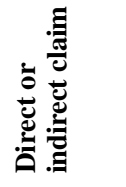 & 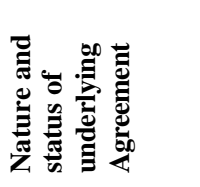 & 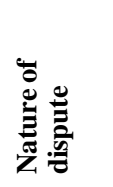 & 旁 & 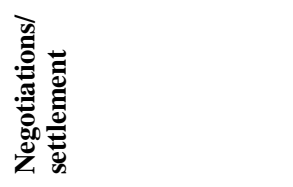 & $\frac{\pi}{\pi}$ \\
\hline $\begin{array}{l}\text { Gas Natural v } \\
\text { Argentina, } \\
\text { Decision on } \\
\text { Jurisdiction } \\
17 \text { June } 2005\end{array}$ & $\begin{array}{l}\text { Gas } \\
\text { supply } \\
\text { and } \\
\text { distribu- } \\
\text { tion }\end{array}$ & ICSID & $\begin{array}{l}\text { Spain- } \\
\text { Argentina } \\
\text { BIT }\end{array}$ & $\begin{array}{l}\text { Indirect } \\
\text { claim by } \\
\text { share } \\
\text { holder }\end{array}$ & $\begin{array}{l}\text { Privatisation of } \\
\text { industry sector }\end{array}$ & $\begin{array}{l}\text { Policy } \\
\text { changes }\end{array}$ & $\begin{array}{l}\text { The dispute in this case relates to the } \\
\text { termination of US dollar based tariffs } \\
\text { and termination of certain tariff } \\
\text { adjustment mechanisms as part of the } \\
\text { foreign exchange reforms taken in an } \\
\text { attempt to remedy the Argentine } \\
\text { financial crisis; the Claimant alleged } \\
\text { expropriation, measures tantamount to } \\
\text { expropriation and breach of fair and } \\
\text { equitable treatment }\end{array}$ & & $\begin{array}{l}\text { The Tribunal assumed } \\
\text { jurisdiction to hear the claims } \\
\text { however the proceedings have } \\
\text { since been suspended pursuant } \\
\text { to an agreement between the } \\
\text { parties. }\end{array}$ \\
\hline $\begin{array}{l}\text { Camuzzi/ } \\
\text { Sempra v } \\
\text { Argentina, } \\
\text { Decisions on } \\
\text { Jurisdiction } \\
11 \text { May 2005 }\end{array}$ & $\begin{array}{l}\text { Gas } \\
\text { supply } \\
\text { and } \\
\text { distribu- } \\
\text { tion }\end{array}$ & ICSID & $\begin{array}{l}\text { Belgium \& } \\
\text { Luxem- } \\
\text { bourg- } \\
\text { Argentina } \\
\text { BIT }\end{array}$ & $\begin{array}{l}\text { Indirect } \\
\text { claim by } \\
\text { share } \\
\text { holder }\end{array}$ & $\begin{array}{l}\text { Privatisation of } \\
\text { industry sector }\end{array}$ & $\begin{array}{l}\text { Policy } \\
\text { changes }\end{array}$ & $\begin{array}{l}\text { The dispute in this case relates to the } \\
\text { termination of US dollar based tariffs } \\
\text { and termination of certain tariff } \\
\text { adjustment mechanisms as part of the } \\
\text { foreign exchange reforms taken in an } \\
\text { attempt to remedy the Argentine } \\
\text { financial crisis; the Claimants have } \\
\text { alleged breach of investment } \\
\text { protections under the relevant } \\
\text { investment treaties }\end{array}$ & & $\begin{array}{l}\text { A Tribunal has assumed } \\
\text { jurisdiction to hear the claims; a } \\
\text { decision on the merits is } \\
\text { pending }\end{array}$ \\
\hline $\begin{array}{l}\text { Petrobart v } \\
\text { Kyrgyzstan, } \\
\text { Award } \\
29 \text { Mar } 2005\end{array}$ & $\begin{array}{l}\text { Gas } \\
\text { supply }\end{array}$ & $\begin{array}{l}\text { Stockholm } \\
\text { Chamber of } \\
\text { Commerce }\end{array}$ & $\begin{array}{l}\text { ECT } \\
\text { (investor } \\
\text { company } \\
\text { incorporate } \\
\text { d under the } \\
\text { laws of } \\
\text { Gibraltar) }\end{array}$ & $\begin{array}{l}\text { Direct } \\
\text { claim by } \\
\text { contrac- } \\
\text { tor }\end{array}$ & $\begin{array}{l}\text { N/A; Delivery } \\
\text { ceased }\end{array}$ & & $\begin{array}{l}\text { The dispute concerns non-payment } \\
\text { under the supply contract and } \\
\text { interference by the authorities to } \\
\text { enforce such payment; the Claimant } \\
\text { alleged breach of the ECT provisions } \\
\text { providing for fair and equitable } \\
\text { treatment and the obligation to provide } \\
\text { effective means for enforce legal rights }\end{array}$ & & $\begin{array}{l}\text { Tribunal awarded pecuniary } \\
\text { damage to Claimant for non- } \\
\text { payment under the contract and } \\
\text { breach of fair and equitable } \\
\text { treatment }\end{array}$ \\
\hline $\begin{array}{l}\text { The Dabhol } \\
\text { Power Project }\end{array}$ & $\begin{array}{l}\text { Power } \\
\text { genera- } \\
\text { tion }\end{array}$ & N/A & $\mathrm{N}^{\prime} / \mathrm{A}^{4}$ & & $\begin{array}{l}\text { Power Purchase } \\
\text { Agreement; } \\
\text { Production and } \\
\text { construction } \\
\text { halted }\end{array}$ & $\begin{array}{l}\text { Policy } \\
\text { change }\end{array}$ & $\begin{array}{l}\text { Dispute concerned failure of a state } \\
\text { agency to pay invoices generated under } \\
\text { the contract and failure of the } \\
\text { government to honour guarantees } \\
\text { granted in connection with the contract }\end{array}$ & $\begin{array}{l}\text { Settlement agreement } \\
\text { reached with two } \\
\text { investors; claims } \\
\text { against the state agency } \\
\text { resulted in pecuniary } \\
\text { damages awarded by } \\
\text { arbitral tribunals }\end{array}$ & N/A \\
\hline $\begin{array}{l}\text { Plama v } \\
\text { Bulgaria, } \\
\text { Decision on } \\
\text { Jurisdiction } \\
\text { 8 Feb 2005 }\end{array}$ & $\begin{array}{l}\text { Power } \\
\text { genera- } \\
\text { tion }\end{array}$ & ICSID & $\begin{array}{l}\text { ECT } \\
\text { (Cypriot } \\
\text { investor) }\end{array}$ & $\begin{array}{l}\text { Indirect } \\
\text { claim by } \\
\text { majority } \\
\text { share } \\
\text { holder }\end{array}$ & N/A & Policy & $\begin{array}{l}\text { The Claimant alleges actions and } \\
\text { omissions of the Government have led } \\
\text { to material damage of the enterprise in } \\
\text { which the Claimant holds a majority } \\
\text { interest; the Claimant has sought } \\
\text { compensation for damages and } \\
\text { expropriation }\end{array}$ & $\mathrm{N} / \mathrm{A}$ & $\begin{array}{l}\text { A Tribunal has assumed } \\
\text { jurisdiction and a decision on } \\
\text { the merits is pending }\end{array}$ \\
\hline
\end{tabular}




\begin{tabular}{|c|c|c|c|c|c|c|c|c|c|}
\hline 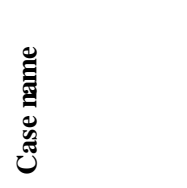 & 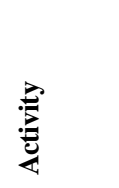 & 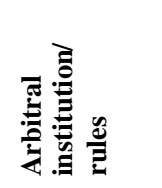 & 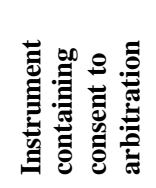 & 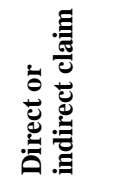 & 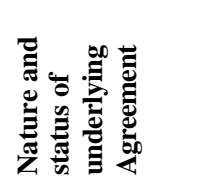 & 范: & 苛 & 商 & 龸 \\
\hline $\begin{array}{l}\text { Enron v } \\
\text { Argentina, } \\
\text { Decision on } \\
\text { Jurisdiction } \\
\text { (Ancillary } \\
\text { Claim) } \\
2 \text { Aug. 2004; } \\
\text { Decision on } \\
\text { Jurisdiction } \\
\text { 14 Jan 2004 }\end{array}$ & $\begin{array}{l}\text { Gas } \\
\text { transport }\end{array}$ & ICSID & $\begin{array}{l}\text { US- } \\
\text { Argentina } \\
\text { BIT }\end{array}$ & $\begin{array}{l}\text { Indirect } \\
\text { claim by } \\
\text { share } \\
\text { holder }\end{array}$ & $\begin{array}{l}\text { Privatisation of } \\
\text { industry sector }\end{array}$ & $\begin{array}{l}\text { Policy } \\
\text { changes }\end{array}$ & $\begin{array}{l}\text { The first dispute relates to Enron's tax } \\
\text { liabilities; the ancillary claim relates to } \\
\text { Argentina's measures taken in } \\
\text { response to the financial crisis. The } \\
\text { Claimant has alleged these actions } \\
\text { amount to expropriation and other } \\
\text { violations of the relevant BIT }\end{array}$ & & $\begin{array}{l}\text { The Tribunal has assumed } \\
\text { jurisdiction to hear both claims }\end{array}$ \\
\hline $\begin{array}{l}\text { PSEG v } \\
\text { Turkey, } \\
\text { Decision on } \\
\text { Jurisdiction } \\
\text { 4 June 2004 }\end{array}$ & $\begin{array}{l}\text { Power } \\
\text { genera- } \\
\text { tion }\end{array}$ & ICSID & $\begin{array}{l}\text { United } \\
\text { States- } \\
\text { Turkey BIT }\end{array}$ & $\begin{array}{l}\text { Direct } \\
\text { claim by } \\
\text { investor }\end{array}$ & $\begin{array}{l}\text { Concession } \\
\text { Contract; } \\
\text { Dispute arose } \\
\text { before } \\
\text { performance } \\
\text { under contract } \\
\text { commenced }\end{array}$ & $\begin{array}{l}\text { Policy } \\
\text { change } \\
\text { alleged }\end{array}$ & $\begin{array}{l}\text { A dispute arose between the parties as to } \\
\text { purchase price and capacity purchase } \\
\text { obligations under the Contract; the } \\
\text { Claimant alleged breach of contract, } \\
\text { breach of treaty protections and } \\
\text { expropriation }\end{array}$ & Negotiations failed & $\begin{array}{l}\text { Tribunal has assumed } \\
\text { jurisdiction to hear case }\end{array}$ \\
\hline $\begin{array}{l}\text { Nykomb } \\
\text { Synergies v } \\
\text { Latvia, } \\
\text { Award } \\
16 \text { Dec } 2003\end{array}$ & $\begin{array}{l}\text { Power } \\
\text { genera- } \\
\text { tion }\end{array}$ & $\begin{array}{l}\text { Stockholm } \\
\text { Chamber of } \\
\text { Commerce }\end{array}$ & $\begin{array}{l}\text { ECT } \\
\text { (Swedish } \\
\text { investor) }\end{array}$ & $\begin{array}{l}\text { Indirect } \\
\text { claim by } \\
\text { sole share } \\
\text { holder }\end{array}$ & $\begin{array}{l}\text { Liberalisation of } \\
\text { energy sector; } \\
\text { Delivery of } \\
\text { energy } \\
\text { continued under } \\
\text { interim } \\
\text { settlement but } \\
\text { further } \\
\text { construction } \\
\text { works halted }\end{array}$ & $\begin{array}{l}\text { Policy } \\
\text { change }\end{array}$ & $\begin{array}{l}\text { The dispute concerned a disagreement } \\
\text { between a domestic energy producer } \\
\text { and a state agency as to the appropriate } \\
\text { tariff rate; the Claimant alleged breach } \\
\text { of contract, violation of the fair and } \\
\text { equitable standard of treatment and } \\
\text { expropriation }\end{array}$ & Negotiations failed & $\begin{array}{l}\text { Tribunal found state liable for } \\
\text { breach of ECT and contractual } \\
\text { obligations }\end{array}$ \\
\hline $\begin{array}{l}\text { AES Summit } \\
\text { Generation v } \\
\text { Hungary, case } \\
\text { discontinued } \\
\text { 3 Jan } 2002\end{array}$ & $\begin{array}{l}\text { Power } \\
\text { gener- } \\
\text { ation }\end{array}$ & N/A & $\begin{array}{l}\text { Unclear on } \\
\text { the basis of } \\
\text { available } \\
\text { information } \\
\text { (US } \\
\text { investor) }\end{array}$ & $\begin{array}{l}\text { Direct } \\
\text { claim by } \\
\text { investor }\end{array}$ & $\begin{array}{l}\text { Privatisation } \\
\text { Agreement; } \\
\text { Project } \\
\text { continued }\end{array}$ & $\begin{array}{l}\text { Policy } \\
\text { change }\end{array}$ & $\begin{array}{l}\text { Claimant's alleged breach of contract } \\
\text { and breach of protections under the } \\
\text { ECT in relation to the government's } \\
\text { refusal to ratify the PPA and failure to } \\
\text { agree to an appropriate power purchase } \\
\text { price }\end{array}$ & $\begin{array}{l}\text { Settlement agreement } \\
\text { reached by parties }\end{array}$ & N/A \\
\hline $\begin{array}{l}\text { Tanzania } \\
\text { Electric } \\
\text { Supply } \\
\text { (TANESCO) } \\
\text { v IPTL, } \\
\text { Award } \\
\text { 12 July } 2001\end{array}$ & $\begin{array}{l}\text { Power } \\
\text { genera- } \\
\text { tion and } \\
\text { distribu- } \\
\text { tion }\end{array}$ & ICSID & $\begin{array}{l}\text { Contract } \\
\text { (Malaysian } \\
\text { investor) }\end{array}$ & $\begin{array}{l}\text { Claim } \\
\text { raised by } \\
\text { State } \\
\text { agency }\end{array}$ & $\begin{array}{l}\text { Power Purchase } \\
\text { Agreement; } \\
\text { Dispute arose } \\
\text { during } \\
\text { construction } \\
\text { phase of project }\end{array}$ & $\begin{array}{l}\text { Contract } \\
\text { dispute }\end{array}$ & $\begin{array}{l}\text { The dispute in this case relates to a failure } \\
\text { between the parties to agree on an } \\
\text { appropriate tariff; both parties alleged } \\
\text { breach of contractual stipulations by the } \\
\text { other party }\end{array}$ & Negotiations failed & $\begin{array}{l}\text { The Tribunal awarded non- } \\
\text { pecuniary remedies in this } \\
\text { award; more precisely, the } \\
\text { Tribunal set the mechanism for } \\
\text { determining the appropriate } \\
\text { tariff, determined questions of } \\
\text { breach of contract and ordered } \\
\text { the parties to perform their } \\
\text { obligations under the contract }\end{array}$ \\
\hline
\end{tabular}




\begin{tabular}{|c|c|c|c|c|c|c|c|c|c|}
\hline 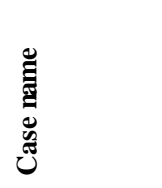 & 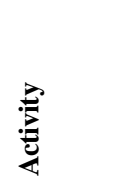 & 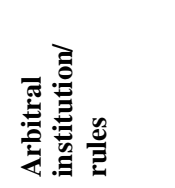 & 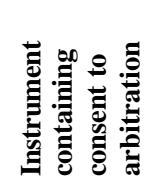 & 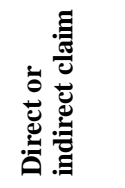 & 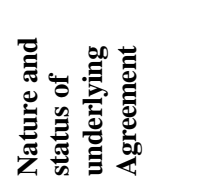 & 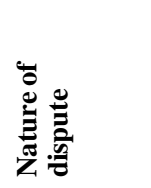 & 莺 & 商 & 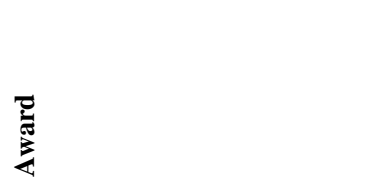 \\
\hline $\begin{array}{l}\text { Himpurna } \\
\text { California v } \\
\text { Indonesia, } \\
\text { Award } \\
4 \text { May } 1999\end{array}$ & $\begin{array}{l}\text { Power } \\
\text { genera- } \\
\text { tion and } \\
\text { distribu- } \\
\text { tion }\end{array}$ & $\begin{array}{l}\text { UNCITRAL } \\
\text { Rules, case } \\
\text { administered } \\
\text { by PCA }\end{array}$ & $\begin{array}{l}\text { Contract } \\
\text { (US } \\
\text { investor) }\end{array}$ & $\begin{array}{l}\text { Direct } \\
\text { claim by } \\
\text { investor }\end{array}$ & $\begin{array}{l}30 \text { year Power } \\
\text { Purchase } \\
\text { Agreement; } \\
\text { Operational site } \\
\text { shut down; other } \\
\text { construction } \\
\text { works } \\
\text { terminated } \\
\end{array}$ & $\begin{array}{l}\text { Policy } \\
\text { change } \\
\text { resulting in } \\
\text { breach of } \\
\text { contract }\end{array}$ & $\begin{array}{l}\text { Claimant's contract suspended in } \\
\text { response to the State's inability to meet } \\
\text { its US dollar obligations in the wake of } \\
\text { the Asian Financial Crisis } 1997 / 98\end{array}$ & Negotiations failed & $\begin{array}{l}\text { Tribunal awarded Claimant } \\
\text { US\$527 million in wasted costs } \\
\text { and lost profits for breach of } \\
\text { contract }\end{array}$ \\
\hline \multicolumn{10}{|c|}{ Telecommunication sector: } \\
\hline $\begin{array}{l}\text { Motorola- } \\
\text { Turkey } \\
\text { Settlement }\end{array}$ & $\begin{array}{l}\text { Mobile } \\
\text { telephony }\end{array}$ & ICSID & $\begin{array}{l}\text { United } \\
\text { States- } \\
\text { Turkey BIT }\end{array}$ & $\begin{array}{l}\text { Direct } \\
\text { claim by } \\
\text { creditor }\end{array}$ & N/A & N/A & $\begin{array}{l}\text { Dispute concerned the prioritisation of } \\
\text { the State's claim against a third party } \\
\text { over that of the Claimant }\end{array}$ & $\begin{array}{l}\text { Settlement agreement } \\
\text { reached under which } \\
\text { the State paid pecuniary } \\
\text { damages to the } \\
\text { Claimant and the } \\
\text { Claimant suspended } \\
\text { arbitral proceedings } \\
\text { and agreed to enforce } \\
\text { its claim against the } \\
\text { third party in certain } \\
\text { specified States }\end{array}$ & N/A \\
\hline $\begin{array}{l}\text { France } \\
\text { Telecom v } \\
\text { Lebanon, } \\
\text { Award } \\
22 \text { Feb } 2005\end{array}$ & $\begin{array}{l}\text { Mobile } \\
\text { telephony }\end{array}$ & $\begin{array}{l}\text { UNCITRAL } \\
\text { Rules }\end{array}$ & $\begin{array}{l}\text { N/A; } \\
\text { (French } \\
\text { investor) }\end{array}$ & $\begin{array}{l}\text { Indirect } \\
\text { claim by } \\
\text { share } \\
\text { holder }\end{array}$ & $\begin{array}{l}\text { Shareholding; } \\
\text { Contract } \\
\text { terminated; } \\
\text { project awarded } \\
\text { to a third party }\end{array}$ & & $\begin{array}{l}\text { Claimant raised a claim on the basis of } \\
\text { early termination of contract }\end{array}$ & Unknown & $\begin{array}{l}\text { Claimant awarded US } \$ 266 \\
\text { million for early termination of } \\
\text { a contract entered into by the } \\
\text { State with the enterprise in } \\
\text { which the Claimant had a } \\
66.66 \% \text { share ownership }\end{array}$ \\
\hline $\begin{array}{l}\text { Nagel v } \\
\text { Czech } \\
\text { Republic }\end{array}$ & $\begin{array}{l}\text { Mobile } \\
\text { telephony }\end{array}$ & $\begin{array}{l}\text { Stockholm } \\
\text { Chamber of } \\
\text { Commerce }\end{array}$ & $\begin{array}{l}\text { United } \\
\text { Kingdom- } \\
\text { Czech } \\
\text { Republic } \\
\text { BIT }\end{array}$ & $\begin{array}{l}\text { Direct } \\
\text { claim }\end{array}$ & $\begin{array}{l}\text { Cooperation } \\
\text { Agreement; } \\
\text { Project not } \\
\text { commenced }\end{array}$ & & $\begin{array}{l}\text { Claimant attempted to enforce a } \\
\text { Cooperation Agreement under which } \\
\text { establishment and operation of a } \\
\text { telecommunications network was } \\
\text { envisaged }\end{array}$ & $\begin{array}{l}\text { Settlement agreement } \\
\text { entered into with state } \\
\text { enterprise but without } \\
\text { prejudice to treaty } \\
\text { claim raised against } \\
\text { State itself }\end{array}$ & $\begin{array}{l}\text { Claim dismissed as no } \\
\text { "investment" under the BIT } \\
\text { (Award rendered in 2003) }\end{array}$ \\
\hline
\end{tabular}




\begin{tabular}{|c|c|c|c|c|c|c|c|c|c|}
\hline 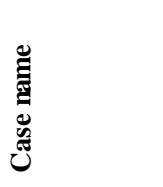 & 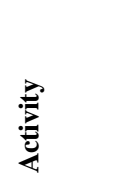 & 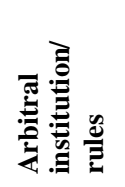 & 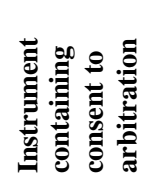 & 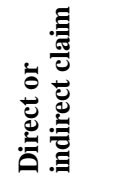 & 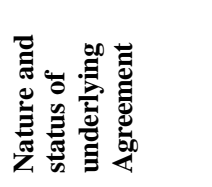 & 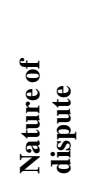 & 窇 & 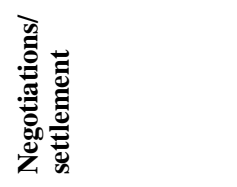 & $\frac{\bar{z}}{2}$ \\
\hline \multicolumn{10}{|c|}{ Transport sector: } \\
\hline $\begin{array}{l}\text { Soufraki v } \\
\text { UAE, } \\
\text { Decision on } \\
\text { Jurisdiction } \\
7 \text { July } 2004\end{array}$ & $\begin{array}{l}\text { Port } \\
\text { manage- } \\
\text { ment and } \\
\text { operation }\end{array}$ & ICSID & $\begin{array}{l}\text { Italy- UAE } \\
\text { BIT }\end{array}$ & $\begin{array}{l}\text { Direct } \\
\text { claim by } \\
\text { investor }\end{array}$ & $\begin{array}{l}\text { Concession } \\
\text { Agreement; } \\
\text { Project status } \\
\text { unknown }\end{array}$ & $\mathrm{N} / \mathrm{A}$ & N/A & N/A & $\begin{array}{l}\text { Tribunal declined jurisdiction } \\
\text { on basis of non-fulfilment of } \\
\text { nationality requirements by } \\
\text { Claimant }\end{array}$ \\
\hline $\begin{array}{l}\text { Aucoven v } \\
\text { Venezuela, } \\
\text { Award } \\
\text { 23 Sept } 2003\end{array}$ & $\begin{array}{l}\text { Highway } \\
\text { mainten- } \\
\text { ance and } \\
\text { operation }\end{array}$ & ICSID & $\begin{array}{l}\text { Contract } \\
\text { (Claimant } \\
\text { treated as } \\
\text { having } \\
\text { Mexican } \\
\text { nationality } \\
\text { through } \\
\text { operation } \\
\text { of Article } \\
\text { 25(2)(b) } \\
\text { ICSID } \\
\text { Convention }\end{array}$ & $\begin{array}{l}\text { Direct } \\
\text { claim by } \\
\text { investor }\end{array}$ & $\begin{array}{l}\text { Concession } \\
\text { Agreement; } \\
\text { Dispute arose } \\
\text { during the life of } \\
\text { the Concession } \\
\text { Contract but } \\
\text { prior to } \\
\text { commencement } \\
\text { of main } \\
\text { construction } \\
\text { works under that } \\
\text { contract. }\end{array}$ & $\begin{array}{l}\text { Policy } \\
\text { change }\end{array}$ & $\begin{array}{l}\text { Dispute related allegations of breach of } \\
\text { contract, cancellation of contract and } \\
\text { the consequences thereof }\end{array}$ & Negotiations failed & $\begin{array}{l}\text { Tribunal found state liable for } \\
\text { certain breaches of contract and } \\
\text { awarded Claimant's pecuniary } \\
\text { damage }\end{array}$ \\
\hline
\end{tabular}

Notes:

1. Because of confidentiality or other reasons, complete information is not available in all cases. N/A indicates that sufficient information is not available to adequately complete the field in question.

2. ICSID has registered a dispute in connection with this case under the name Biwater Gauff (Tanzania) Ltd v Tanzania (ICSID Case No ARB/05/22), however, from the information available the place of incorporation of this corporate vehicle is unclear, nor is it apparent how nationality requirement will be satisfied under the ICSID Convention.

3. The ICSID Centre website lists this case as arising in the "gas transmission" sector, however, the Tribunal states the enterprise to be involved in "gas transportation." This latter language has been used so as to provide consistent use of language where possible. In all other ICSID cases arising from the Argentine financial crisis, the industry sector listed is as stated by the ICSID Centre website.

4. While the three investors involved in this project were reported to be enterprises incorporated under the law of the United States, it is unclear from the information available whether the investment took place through these companies directly or through subsidiary c ompanies incorporated in other jurisdictions. 
Table 2. Arbitral decision \& negotiated settlements in cases related to the construction of infrastructure

\begin{tabular}{|c|c|c|c|c|c|c|c|c|c|}
\hline 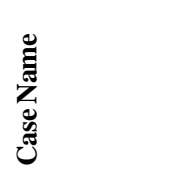 & 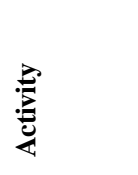 & 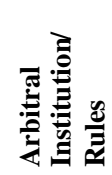 & 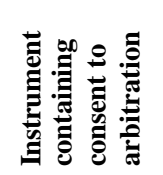 & 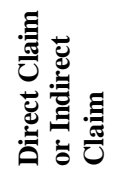 & 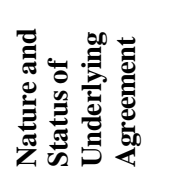 & 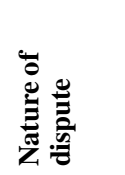 & 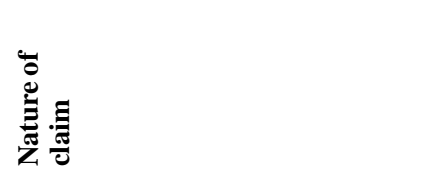 & 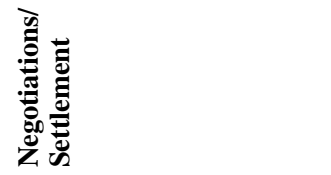 & 茪 \\
\hline $\begin{array}{l}\text { Bayindir v } \\
\text { Pakistan, } \\
\text { Decision on } \\
\text { Jurisdiction } \\
14 \text { Nov } 2005\end{array}$ & $\begin{array}{l}\text { Highway } \\
\text { construc- } \\
\text { tion }\end{array}$ & ICSID & $\begin{array}{l}\text { Turkey- } \\
\text { Pakistan } \\
\text { BIT }\end{array}$ & $\begin{array}{l}\text { Direct } \\
\text { claim by } \\
\text { contractor }\end{array}$ & $\begin{array}{l}\text { Construction } \\
\text { contract; } \\
\text { Contract } \\
\text { terminated } \\
\text { and project } \\
\text { awarded to } \\
\text { third party. }\end{array}$ & $\begin{array}{l}\text { Contract } \\
\text { dispute }\end{array}$ & $\begin{array}{l}\text { The dispute relates to the consequences } \\
\text { of late handover of land to the } \\
\text { contractor. The claimant alleged breach } \\
\text { of contract and breach of treat provisions } \\
\text { regarding fair and equitable treatment, } \\
\text { most favoured nation treatment and } \\
\text { expropriation. }\end{array}$ & $\begin{array}{l}\text { Certain earlier claims were } \\
\text { settled by agreement } \\
\text { between the parties. }\end{array}$ & $\begin{array}{l}\text { An ICSID Tribunal has assumed } \\
\text { jurisdiction to hear claims based on } \\
\text { breach of treaty }\end{array}$ \\
\hline $\begin{array}{l}\text { Impregilo v } \\
\text { Pakistan, } \\
\text { Decision on } \\
\text { Jurisdiction } \\
22 \text { April } 2005\end{array}$ & $\begin{array}{l}\text { Power } \\
\text { generation }\end{array}$ & ICSID & $\begin{array}{l}\text { Italy- } \\
\text { Pakistan } \\
\text { BIT }\end{array}$ & $\begin{array}{l}\text { Direct } \\
\text { claim by } \\
\text { contractor }\end{array}$ & $\begin{array}{l}\text { Construction } \\
\text { Contract; } \\
\text { Construction } \\
\text { works } \\
\text { completed }\end{array}$ & $\begin{array}{l}\text { Contract } \\
\text { dispute }\end{array}$ & $\begin{array}{l}\text { Claimant alleged breach of contract and } \\
\text { breach of fair and equitable treatment } \\
\text { under the BIT and expropriation of } \\
\text { investment or measures tantamount to } \\
\text { expropriation contrary to the provisions } \\
\text { of the BIT }\end{array}$ & $\begin{array}{l}\text { An Agreement between the } \\
\text { parties settled some of the } \\
\text { issues in dispute between } \\
\text { the parties. }\end{array}$ & $\begin{array}{l}\text { An ICSID Tribunal has assumed } \\
\text { jurisdiction to hear claims based on } \\
\text { breach of treaty }\end{array}$ \\
\hline $\begin{array}{l}\text { L.E.S.I.- } \\
\text { Dipenta v } \\
\text { Algeria, } \\
\text { Decision on } \\
\text { Jurisdiction } \\
10 \text { January, } \\
2005\end{array}$ & $\begin{array}{l}\text { Power } \\
\text { generation }\end{array}$ & ICSID & $\begin{array}{l}\text { Italy- } \\
\text { Morocco } \\
\text { BIT }\end{array}$ & $\begin{array}{l}\text { Direct } \\
\text { claim by } \\
\text { contractor }\end{array}$ & $\begin{array}{l}\text { Construction } \\
\text { contract; } \\
\text { Contract } \\
\text { terminated } \\
\text { and } \\
\text { construction } \\
\text { halted }\end{array}$ & $\begin{array}{l}\text { Contract } \\
\text { dispute }\end{array}$ & $\begin{array}{l}\text { The Claimant attempted to recoup } \\
\text { expenses incurred during construction } \\
\text { works and damages for cancellation of } \\
\text { contract }\end{array}$ & Negotiations failed & $\begin{array}{l}\text { ICSID Tribunal refused jurisdiction } \\
\text { ratione personae as the arbitral } \\
\text { claim was raised by the consortium } \\
\text { itself while the construction } \\
\text { contract was entered into by the two } \\
\text { consortium members individually. }\end{array}$ \\
\hline $\begin{array}{l}\text { Salini v } \\
\text { Jordan, } \\
\text { Decision on } \\
\text { Award of } \\
\text { 31 Jan } 2006\end{array}$ & $\begin{array}{l}\text { Power } \\
\text { generation }\end{array}$ & ICSID & $\begin{array}{l}\text { Italy-Jordan } \\
\text { BIT } \\
\text { (despite an } \\
\text { exclusive } \\
\text { jurisdiction } \\
\text { clause in } \\
\text { the } \\
\text { contract) }\end{array}$ & $\begin{array}{l}\text { Direct } \\
\text { claim by } \\
\text { contractor }\end{array}$ & $\begin{array}{l}\text { Construction } \\
\text { Contract; } \\
\text { Construction } \\
\text { works } \\
\text { completed }\end{array}$ & $\begin{array}{l}\text { Contract } \\
\text { dispute }\end{array}$ & $\begin{array}{l}\text { Dispute relates to final payment under } \\
\text { the contract }\end{array}$ & Negotiations failed & $\begin{array}{l}\text { The Tribunal dismissed all claims } \\
\text { against the Kingdom of Jordan on } \\
\text { the ground the Claimant had not } \\
\text { established the existence of an } \\
\text { arbitration agreement between the } \\
\text { parties. }\end{array}$ \\
\hline $\begin{array}{l}\text { Consortium } \\
\text { RFCC v } \\
\text { Morocco, } \\
\text { Award 22 } \\
\text { December } \\
2003\end{array}$ & $\begin{array}{l}\text { Highway } \\
\text { constructio } \\
\mathrm{n}\end{array}$ & ICSID & $\begin{array}{l}\text { Italy- } \\
\text { Morocco } \\
\text { BIT }\end{array}$ & $\begin{array}{l}\text { Direct } \\
\text { claim by } \\
\text { contractor }\end{array}$ & $\begin{array}{l}\text { Construction } \\
\text { contract; } \\
\text { Dispute arose } \\
\text { post- } \\
\text { completion of } \\
\text { construction } \\
\text { works }\end{array}$ & $\begin{array}{l}\text { Contract } \\
\text { dispute }\end{array}$ & $\begin{array}{l}\text { Dispute related to final payment due } \\
\text { under the contract and the parties' } \\
\text { respective contractual obligations }\end{array}$ & $\begin{array}{l}\text { Partial interim agreement } \\
\text { reached between the } \\
\text { parties during the } \\
\text { construction phase; } \\
\text { negations regarding } \\
\text { payment failed }\end{array}$ & $\begin{array}{l}\text { Tribunal found no jurisdiction over } \\
\text { contract claims and rejected } \\
\text { allegations of treaty violation; } \\
\text { decision on annulment pending }\end{array}$ \\
\hline
\end{tabular}




\begin{tabular}{|c|c|c|c|c|c|c|c|c|c|}
\hline 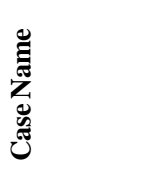 & : & 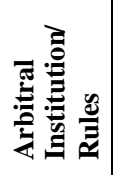 & 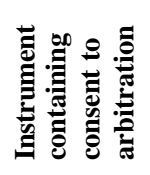 & 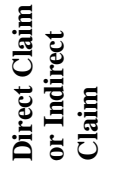 & 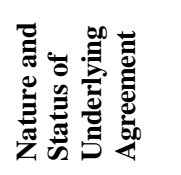 & 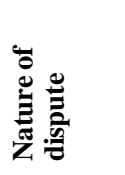 & 离 & 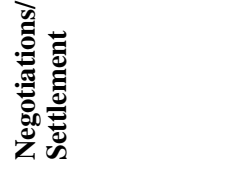 & 葛 \\
\hline $\begin{array}{l}\text { Mihaly } \\
\text { International } \\
\text { v Sri Lanka, } \\
\text { Award } \\
15 \text { Mar } 2002\end{array}$ & $\begin{array}{l}\text { Construc- } \\
\text { tion of } \\
\text { power } \\
\text { generation } \\
\text { facilities }\end{array}$ & ICSID & $\begin{array}{l}\text { United } \\
\text { States-Sri } \\
\text { Lanka BIT }\end{array}$ & $\begin{array}{l}\text { Direct } \\
\text { claim by } \\
\text { investor }\end{array}$ & $\begin{array}{l}\text { No contract } \\
\text { finalised }\end{array}$ & & $\begin{array}{l}\text { Claimant raised an action to recover } \\
\text { its pre-establishment expenditures } \\
\text { after initial discussions between the } \\
\text { parties failed to mature into a contract }\end{array}$ & & $\begin{array}{l}\text { ICSID Tribunal refused jurisdiction } \\
\text { ratione materiae over pre- } \\
\text { establishment expenditures in the } \\
\text { absence of a contract }\end{array}$ \\
\hline $\begin{array}{l}\text { Salini v } \\
\text { Morocco, } \\
\text { Award } \\
\text { 23 July } 2001\end{array}$ & $\begin{array}{l}\text { Highway } \\
\text { construc- } \\
\text { tion }\end{array}$ & ICSID & $\begin{array}{l}\text { Italy- } \\
\text { Morocco } \\
\text { BIT }\end{array}$ & $\begin{array}{l}\text { Direct } \\
\text { claim by } \\
\text { contractor }\end{array}$ & $\begin{array}{l}\text { Construction } \\
\text { contract; } \\
\text { Dispute arose } \\
\text { post- } \\
\text { completion of } \\
\text { construction } \\
\text { works } \\
\end{array}$ & $\begin{array}{l}\text { Contract } \\
\text { dispute }\end{array}$ & $\begin{array}{l}\text { Dispute related to final payment due } \\
\text { under the contract and further alleged } \\
\text { expropriation contrary to the treaty } \\
\text { provisions }\end{array}$ & Negotiations failed & Tribunal has assumed jurisdiction \\
\hline
\end{tabular}


13. Similarities may also be drawn between certain cases with respect to the underlying issues forming the basis of the claim. The cases may be broadly divided into two categories: (a) those cases where the circumstances or facts underlying the dispute relate to state policy or policy measures taken by the government and (b) those where the underlying issues are purely of a contractual nature. The clearest examples of policy forming the basis of the dispute are the cases arising out of the Asian and Argentinean financial crises. Also falling into this category of claims are cases where public opinion has opposed the project.

14. Fourteen of the cases canvassed in this study may be categorised as relating to policy considerations whereas seven relate purely to obligations arising under contract. A further seven cases do not fall into either category, either because the dispute cannot be easily categorised as pertaining to policy or contract or because the relevant information is not available to make this determination.

15. Regarding the sectoral distribution of cases, three cases so far relate to concessions in the water and sewerage sector. The Aguas del Tunari v Bolivia claim ${ }^{1}$ and the Biwater Dispute, ${ }^{2}$ none of which has yet been concluded, both arose from the cessation of contracts by the host country authorities. In the first case authorities did so in response to widespread public protest. In the second both parties allege breach of contract. The authorities claim that the contractor failed to honour its service commitments; the contractor claims that the authorities have provided erroneous information about the terms of the concession. In Vivendi $v$ Argentina the claimant alleges to have been the victim of obstruction from the local authorities in its concession area, whereas the Argentine authorities argue that the claimant has breached its service commitments.

16. The energy sector - with information regarding 13 cases already in the public domain, not counting construction cases - is the most strongly represented area. Six cases relate to gas supply or distribution; eight relate to power generation or supply. Nine of the cases have been finally resolved, two of which through a settlement agreement between the parties.

17. Five of the cases involve Argentina - in particular the measures authorities took to weather the Argentine financial crisis. Four of these cases are alleged breaches of BITs between Argentina and various OECD countries; the fifth was brought before OPIC Tribunal. All claimants have alleged that the Argentine authorities, by denying investors the right to tariff adjustments previously agreed, are in breach of contract, in breach of fair and equitable treatment and/or have undertaken an act of expropriation. The OPIC Tribunal concluded that the claimant, Ponderosa Assets, ${ }^{3}$ had suffered an act of expropriation as the authorities' actions had effectively extinguished the value of the investor's investment. The only arbitrational award so far relates to CMS Gas Transmission v Argentina. ${ }^{4}$ The Tribunal rejected claims of expropriation but held Argentina liable for breach of contract and breach of fair and equitable treatment. Argentina has instituted annulment proceedings against this decision.

1. Aguas del Tunari, S.A. v Republic of Bolivia (ICSID Case No. ARB/02/3), Decision on Jurisdiction, 21 October 2005.

2. Biwater Gauff (Tanzania) Limited v. United Republic of Tanzania (ICSID Case No. ARB/05/22).

3. OPIC Award regarding Ponderosa Assets of 2 August, 2005.

4. CMS Gas Transmission Company v. Argentine Republic (ICSID Case No. ARB/01/8). 
18. One case, Petrobart v Kyrgyzstan, ${ }^{5}$ relates to gas supply. In this, the second final award rendered under the Energy Charter Treaty, the Tribunal (Stockholm Chamber of Commerce) sided largely with the investor's assertion that a failure of national authorities to provide effective means to enforce legal rights constituted a breach of fair and equitable treatment. The seven other cases relate to power generation and distribution. Six of them are founded in alleged host country policy changes, leading investors to assert breach of contract, breach of fair and equitable treatment and/or expropriation. In most cases the point of contention was government intervention in cases of public discontent or inability of domestic agencies to honour their contractual obligations. Two of these cases (PSEG $v$ Turkey $^{6}$ and Himpurna California $v$ Indonesia $)^{7}$ have been concluded with the Tribunals ruling in favour of the investors, awarding compensation for breach of treaty and contractual obligation.

19. Three cases in the telecommunication sector all relate to mobile telephony but they differ substantially. The Motorola $v$ Turkey $^{8}$ dispute, relating to the Turkish State's alleged prioritisation of its own claims against a financially distressed company, ended with a settlement agreement in which the State paid pecuniary damages. In France Telecom $v$ Lebanon a Tribunal awarded the claimant compensation for early termination of a contract, as the Lebanese authorities granted a telephone concession to a third party. Nagel $v$ Czech Republic ${ }^{10}$ related to a cooperation agreement that failed to produce the expected benefits to the claimant. A Tribunal dismissed the claim, finding that the agreement did not qualify as "investment" under the relevant BIT.

20. So far only two cases in the transport sector have made it to the public domain. A widely quoted dispute, Aucoven v Venezuela, ${ }^{11}$ concerned a highway concession contract and a failure by the State to put in place the agreed tariffs due to popular protests. The concession was ultimately abandoned by the claimant and was awarded pecuniary damages by an ICSID Tribunal. Although the Tribunal rejected the State's claim that the public unrest surrounding the concession qualified as force majeure, it did not award the claimant substantial compensation for lost profits. The other dispute, Soufraki v United Arab Emirates, ${ }^{12}$ related to a claim that the regulators stymied the claimant's development of a seaport in violation of the provisions in a BIT. However, the Tribunal declined jurisdiction on the basis of nonfulfilment of nationality requirements.

21. Seven cases relate to the construction of infrastructure. All seven disputes arose from BITS between OECD and non-OECD countries. Six of them were essentially contractual disputes, and one was

5. Petrobart Limited v The Kyrgyz Republic, Award of 29 March 2005, SCC Case No 126/2003.

6. PSEG Global Inc, The North American Coal Corporation, and Konya Ilgin Elektrik Üretim ve Ticaret Limited Sirketi v Republic of Turkey, Decision on Jurisdiction 4 June 2004 (ICSID Case No ARB/02/5).

7. Himpurna California Energy Ltd. (Bermuda) v PT. (Persero) Persusahaan Listruik Negara (Indonesia), Final Award of 4 May 1999, reported in 14 Mealey's International Arbitration Report pp. A-1 - A-58.

8. Motorola Credit Corporation, Inc v Republic of Turkey (ICSID Case No. ARB/04/21).

9. France Telecom v Lebanon, Award 22 February, 2005 (UCITRAL Arbitration).

10. Nagel v Czech Republic, Final Award, (Stockholm Chamber of Commerce Case 49/2002).

11. Autopista Concesionada de Venezuela, C.A. ('Aucoven') v Bolivarian Republic of Venezuela (ICSID Case No. ARB/00/5), Award 23 September 2003.

12. Hussein Numan Soufrakiv The United Arab Emirates, Decision on Jurisdiction 7 July 2004 (ICSID Case No. ARB/02/7). 
rejected by the Tribunal on account of the absence of a contract. Many of the claims relate to the final payment under the respective contracts and may be of limited broader relevance in the context of infrastructure investment. However, two cases (Bayindir v Pakistan ${ }^{13}$ and Impreglio v Pakistan ${ }^{14}$ ) over which Tribunals recently assumed jurisdictions related to a broader set of issues, including alleged breach of fair and equitable treatment and expropriation, in connection with the host country's regulatory and expropriation processes.

\section{2) Tentative conclusions}

22. From the reviewed arbitral jurisprudence, certain conclusions offer themselves. ${ }^{15}$ These should not, however, be considered as a commentary on or an attempt to influence the future evolution of arbitral jurisprudence or in any other way considered as a legal interpretation.

23. In a significant number of cases the disputes have related, in whole or in part, to tariff adjustments. With the exception of the TANESCO ${ }^{16}$ arbitration, all of these disputes have policy changes as their root cause. The majority of these cases can be broadly grouped into two categories: (i) cases where public resistance has led to the policy change and; (ii) cases where policy changes have occurred as a consequence of a financial crisis, in particular making it difficult for the State party to meet its obligations where the tariff has been linked to a foreign currency.

24. An example of the first category of cases is the Aucoven ${ }^{17}$ arbitration where violent public protest led to a governmental decision not to impose tariffs according to an agreed schedule. Also falling within this category of cases is Aguas del Tunari, ${ }^{18}$ Vivendi $^{19}$ and the Dabhol Power Project. In two cases, one from each sub-group, force majeure has been invoked by the State as a ground precluding wrongfulness of the State for its breach of treaty obligation, however, in neither of these cases has the defence been successful (Himpurna ${ }^{20}$ and Aucoven ${ }^{21}$ ). Nor was the defence of necessity successfully argued by Argentina in $C M S^{22}$

13. Bayindir Insaat Turizm Ticaret Ve Sanayi A.S. v Pakistan, Decision on Jurisdiction, 14 November 2005 (ICSID Case No. ARB/03/29).

14. Impregilo S.p.A. v Islamic Republic of Pakistan, Decision on Jurisdiction, 22 April 2005 (ICSID Case No. ARB/03/3).

15. Arbitrations involving infrastructure projects have evolved as part of, and not in isolation from, arbitral jurisprudence relating to other sectors. As such, the resolution of disputes in infrastructure projects should be viewed from the perspective of this wider body of arbitral jurisprudence.

16. Supra note 5 .

17. Supra note 16 .

18. Supra note 6 .

19. Compañia de Aguas del Aconquija, S.A. \& Compagnie Générale des Eaux v The Argentine Republic (ICSID Case No. ARB/97/3).

20. Supra note 12 .

21. Supra note 16 .

22. $\quad$ Supra note 4 . 
25. Within the group of cases relating specifically to construction of infrastructure, the disputes broadly appear to fall under two banners: disputes relating to allegations of breach of specific contractual stipulations and disputes relating to the final payments due under the contract. With the exception of two cases (Bayindir ${ }^{23}$ and Impregilo ${ }^{24}$ ) disputes arising under this category of cases appear to concentrate almost exclusively on contractual liability.

26. It also appears common for States to attempt to counter-claim or off-set the investors' claims, in particular through alleging breach of service agreements or raising technical reservations as grounds for termination of contract. However, the absence of such counter-claims in a particular dispute does not necessarily preclude these claims from being raised in separate and independent proceedings.

27. A large number of disputes are, at present, still pending. However, from the disputes where a final award on the merits has been rendered it appears that the main heads of treaty violation successfully invoked by claimant investors are breach of contract and breach of fair and equitable treatment. By contrast, expropriation has rarely been successfully invoked; of the arbitral jurisprudence reviewed, only the award rendered by the OPIC Tribunal found an expropriatory act by the State ${ }^{25}$ In order to successfully claim for breach of contract a contract must exist between the investor and the State or an organ of the State, there must be a breach of that contract and such breach must be elevated to the international sphere, for example through the operation of an umbrella clause or a broad dispute resolution clause.

28. The three instances where a violation of the fair and equitable standard of treatment has been found to exist have all been rendered within the last three years. This standard of protection has been increasingly raised in recent arbitral practice; it would seem that arbitrations relating to infrastructure are no exception. ${ }^{26}$ A considerable number of the infrastructure arbitrations currently pending include allegations of breach of this standard of treatment.

29. The reviewed arbitral jurisprudence seems to indicate that, as with other sectors, pecuniary damages are regarded as the most appropriate remedy in infrastructure related disputes. In only one case, the TANESCO Award, ${ }^{27}$ was the relief entirely non-pecuniary in nature. However, the actual amount of damages awarded to investors appears to often be less than the relief requested, occasionally significantly so, i.e. in both Himpurna ${ }^{28}$ and Aucoven ${ }^{29}$ cases (in the latter case the damages represented only $10 \%$ of the requested relief).

23. Supra note 18.

24. Supra note 19.

25. OPIC Award regarding Ponderosa Assets of 2 August, 2005.

26. See Yannaca-Small, Fair and Equitable Treatment in International Investment Law, International Investment Law: A Changing Landscape, OECD, 2005; Schreuer, A Decade of Increasing Awareness of Investment Arbitration and Intensive Activity: An Assessment, ICSID, OECD and UNCTAD Symposium on Making the Most of International Investment Agreements: A Common Agenda, Paris 12 December 2005 available at: http://www.oecd.org/dataoecd/5/54/36055388.pdf

27. Supra note 5.

28. Supra note 12 .

29. Supra note 16. 


\section{REVIEW OF THE CASE EVIDENCE}

30. The present section provides an outline of the factual circumstances and legal arguments that arose in the cases already listed in Tables 1 and 2 of the Introduction and Summary. Where information additional to that found in the text of arbitral decisions is available, this is included at the end of the case information and with the corresponding references. The section is divided into two main parts.

31. The first part concerns arbitrations and settlement agreements that arose from concessions and other contracts concerning infrastructure services. Cases are listed according to the activities or part of the infrastructure sector they principally concern. As part of the sub-section on cases in the energy sector, special mentioning is made of the cases arising from the Argentine financial crisis. This attribution is due to the fact that the Argentine cases that have so far resulted in final awards concern energy. A number of cases relating to other sectors are still pending; it is not clear to what extent existing decisions will be indicative of the arguments that may arise and the manner in which these disputes may be resolved.

32. A second part lists cases that have arisen from the construction of infrastructure. The disputes from the two types of involvement in infrastructure projects often differ. First and foremost, most disputes related to infrastructure services relate, even if sometimes indirectly, to the concession agreements at the heart of these projects. Disputes arising from the construction of infrastructure are often functionally equivalent to the ones related to other kinds of construction.

33. Finally, and again, while attempts have been made to provide as much pertinent information as possible, because of confidentiality or other reasons information regarding certain disputes is not in the public domain and thus cannot be included in the present study.

\section{Arbitrations and settlement agreements in infrastructure projects}

\section{1) Telecommunications}

Nagel v Czech Republic, Final Award, (Stockholm Chamber of Commerce Case 49/2002). The dispute relates to a Cooperation Agreement entered into between the Claimant and a State Agency for development of a telecommunications network. The Licence was ultimately granted to a third party and the Claimant attempted to enforce the Agreement. The Tribunal, however, determined that the Agreement did not amount to an "investment."

34. In 1993, the Claimant in this case entered into a Cooperation Agreement with a state enterprise under which the parties to the Agreement "would jointly seek to obtain the necessary licences and other permits to establish, own and operate a telecommunications business in the Respondent's territory." Following a governmental Resolution concerning state telecommunications policy, a licence was to be "awarded to the State Enterprise and a partner to be chosen by tender." Ultimately the tender was awarded to a German consortium rather than the Claimant. Following this development, the Claimant initiated court proceedings against the State Enterprise seeking damages for breach of contract. A 
Settlement Agreement was entered into under which the Claimant received US\$550 000 and waived all past, present or future claims against the State Enterprise with respect to the Cooperation Agreement. The Claimant nevertheless initiated arbitral proceedings against the Republic arguing the Resolution deprived the Claimant of his rights under the Cooperation Agreement in breach of the provision on expropriation of the relevant investment protection agreement.

35. The Tribunal considered the effect of the Settlement Agreement did not to deprive the Tribunal of jurisdiction over the claim. In particular, the Tribunal considered the Settlement Agreement related to allegations of breach of contract raised in domestic court proceedings and, on its terms, applied only between the parties signatory to that Agreement, i.e. the Claimant and the State Enterprise. By contrast, the treaty claim alleged breach of treaty protection and was directed against the Republic. Ultimately, however, the Tribunal rejected the claim on the basis that: (i) the State Enterprise was a separate le gal person whose actions did not engage the responsibility of the State; (ii) insofar as the terms of the Cooperation Agreement did not guarantee obtaining the required licence, it could not give rise to a legitimate expectation of the Claimant; (iii) the Cooperation Agreement did not bind the State in its choice of licensee for the reasons stated above and; (iv) the Agreement constituted preparatory work but did not in itself contain a financial value or require the making of payments on the part of the Claimant, as such it did not amount to an 'asset' or 'investment' under the applicable BIT.

Motorola-Turkey Settlement: Motorola Credit Corporation, Inc. v. Republic of Turkey (ICSID Case No. ARB/04/21). ${ }^{30}$ The dispute relates to the State's prioritisation of its own claim against a third party over that of the Claimant. The parties reached a settlement agreement and suspended their arbitral claim. In October 2005 Motorola and Turkey reached a settlement agreement which effectively terminated Motorola's claim against the State.

36. The dispute arose out of a series of loans made by Motorola to Telsim, a Turkish mobile phone network owned by the Uzan family, to the amount of US $\$ 2.5$ billion. Telsim repeatedly defaulted on its repayments and Motorola took steps to recover its debts. To this end, Motorola initiated commercial arbitration in the United States and was awarded US $\$ 4.26$ billion, reflecting the entirety of its claim and damages for fraudulent activity of the Uzan family who apparently had not invested the loan amount in development of the telecommunications network and was found to not have had the intention of repaying the loan. Concurrently, investigations by the Turkish authorities revealed other irregularities in the manner in which the Uzan family had conducted its other businesses. In particular, the Imar Bank was found to have accumulated a US\$6 billion deficit. Investigations revealed the majority of this money had gone to support the family's other holdings or into private accounts.

30. See e.g. Court Awards Motorola \$4.6 Million in Telsim Suit; But Uzan Family Can't Be Located, RCR Wireless New, 6 October 2003; Turkey Requests Extradition of Fugitive Turkish Tycoons From United States, Associated Press, December 8 2003; Motorola, Turkey Chase Family for Missing Billions, Chicago Tribune, December 28 2003; The Collapse of the Uzan Empire, Financial Times, February 16 2004; Uzan Family Companies Seized by Turkish State to Recover Multi-Billion Dollar Debts, World Markets Research, February 17 2004; Takeover May Put Turkey on Hook for Firm's Debt to Motorola, Nokia, Chicago Sun-Times, February 17 2004; Uzan Says He Sought Deals; Motorola Lawyer Dismisses Offers, Chicago Tribune, March 2 2004; Cem Uzan Maintains His Battle, Financial Times, November 19 2004; Den of Thieves, The Economist, March 19 2005; Motorola Far From Collecting Its Due, Chicago Tribune, August 5 2005; Nokia Reaches Compensation Deal Through Government's Telsim Sale, World Markets Research, August 30 2005; Motorola Settles on Telsim, TheStreet.com, October 28 2005; Motorola, Telsim Settle Fraud Suit, Chicago Daily He rald, 29 October 2005. 
37. When this information became public, a run began on the bank and the Turkish authorities took control of the bank in accordance with its regulatory powers. Under the Turkish regulatory framework, all deposits into banks were guaranteed by the State. Accordingly, the Imar Bank had a US\$6 billion debt to the government. To recover the amounts owed to it, the Turkish government seized other assets belonging to the Uzan family, including Telsim. The effect of these seizures was to deny Motorola access to assets against which it could enforce its arbitral award. Motorola raised a claim under the auspices of ICSID arguing that the priority given to the Turkish financial claim over that of Motorola violated investor protection provisions of the US-Turkey BIT. In a settlement agreement, Turkey agreed to pay Motorola US $\$ 500$ million and a percentage of the proceeds of sale of Telsim over US $\$ 2.5$ billion. Motorola, for its part, agreed $\mathbf{b}$ drop its ICSID claim and any other litigation against the Turkish authorities and to seek enforcement of its arbitral award against Telsim outside of Turkey and certain other specified states. A similar agreement has apparently been reached with Nokia who also had outstanding loans to Telsim.

France Telecom v Lebanon Award 22 February, 2005 (UCITRAL Arbitration). While a text of the Final Award has not yet been made available, a France Telecom Press Release dated February 22, 2005 reports that it was awarded US\$266 million in relation to the early termination of a BOT contract entered into by an enterprise in which France Telecom owns a $66.66 \%$ interest.

38. The contract concerned construction and operation of Lebanon's mobile phone network. The dispute arose in 2001 when the commission was transferred to Deutsche Telekom. While France Telecom argued the contracts were "unlawfully terminated to clear the way for licence auctions," Lebanon counter-claimed France Telecom had breached the terms of its contract and owed the government US $\$ 300$ million in unpaid taxes and penalties. ${ }^{31}$

- $\quad$ Cases pending

- Telenor Mobile Communications AS v. Republic of Hungary (ICSID Case No. ARB/04/15) Telecommunications concession, Decision pending

- Rumeli Telekom A.S. \& Telsim Mobil Telekomunikasyon Hizmetleri A.S. v. Republic of Kazakhstan (ICSID Case No. ARB/05/16) Telecommunications enterprise, Tribunal not yet constituted

- Telekom Malaysia Berhad v Government of Ghana (arbitration being conducted under the UNCITRAL Rules by the Permanent Court of Arbitration)

\section{2) Transportation}

Autopista Concesionada de Venezuela, C.A. (“Aucoven”) v Bolivarian Republic of Venezuela, Award 23 September 2003 (ICSID Case No. ARB/OO/5). This case concerns a highway concession contract and a failure by the State to put in place the agreed tariffs due to popular protest; the concession was ultimately abandoned by the Claimant. An ICSID Tribunal awarded the Claimant pecuniary damage.

31. Lebanese Government to Challenge France Telecom's Arbitration Claim, World markets Research February 24, 2005; Motorola agrees to settle Telsim claims, Financial Times October 29, 2005. 
39. In April 1994 the government of Venezuela put in place the legislative framework necessary to grant concessions of "public works and services to private companies". ${ }^{32}$ In December 1994, the government put the Caracas-La Guaira Highway System up for bid; the project proposal included construction of a Bridge to replace an existing, unsafe viaduct. In addition the Concessionaire was to undertake other construction works and maintain and operate the highway system for a period of 30 years. Revenues were expected to come from collection of tolls on the highway during the concession period; in this respect it was understood that existing toll rates would need to be increased in order to meet the project's financing requirements. In December 1995 the Concession was awarded to the Claimant; the terms of the Concession Agreement reflected the intended objectives of the highway renewal project and, in addition, included an obligation on the Claimant to undertake works on the free alternate route linking Caracas to La Guaira during the first two years of the Concession. Venezuela's obligations under the contract related mainly to financial aspects of the project including, inter alia, the obligation to act as guarantor to the Claimant's loans upon request of the Claimant, to guarantee a minimum income in the event the returns on toll fees fell below a minimum threshold and to increase the existing highway tolls pursuant to a specified schedule.

40. Due to public resistance, however, the toll increases did not take place according to the agreed schedule. In response, the parties entered into an Agreement intended to make the project more attractive to the public; the parties also agreed to a change in the toll increase arrangement whereby the burden would shift from private to commercial traffic. This proposal, however, resulted in "major protests from trucking companies and officials of the State of Vargas, where much of the commercial traffic using the Highway System originates". The toll rates ultimately imposed by Venezuela in 1997 fell far below the previously agreed levels and as such were insufficient to meet the financing requirements for the construction envisaged under the Concession Contract. Although the parties entered into negotiations to refinance the project, political opposition frustrated these negotiations. When a new government was elected in 1998, it initiated legal proceedings in an attempt to have the Concession Agreement declared null and void.

41. The Claimant unilaterally terminated the Concession Agreement in June 2000 but nevertheless indicated a willingness to continue to collect tolls and perform routine maintenance on the Highway System. Violent protests in August 2002, led by truck drivers, ultimately forced the Claimant to abandon the highway. Upon termination of the Concession Agreement, the Claimant initiated ICSID arbitration pursuant to a dispute resolution provision in the contract. In its request for arbitration, the claimants sought relief in excess of 25 billion bolivars for out-of-pocket expenses, lost profits and interest thereon.

42. The Tribunal held Venezuela to be liable for a number of breaches of obligation arising under the Concession Agreement, including failure to raise the tolls, failure to provide a guarantee for a loan and breach of the exclusive jurisdiction clause conferring disputes under the contract to arbitration by initiation of domestic proceedings. By contrast, Venezuela was not held liable for breach of contract for certain financial arrangements under the contract where the Claimant failed to provide relevant information or updates in respect of the minimum guaranteed income mechanism. Nor did the Tribunal find that Venezuela had breached its duty to act in good faith: "the Arbitral Tribunal can see no legal

\footnotetext{
32. Autopista Concesionada de Venezuela, C.A. (“Aucoven”) v Bolivarian Republic of Venezuela, Award (ICSID Case No. ARB/00/5) at para. 10.

33. At para. 36 .
} 
foundation to find a breach of good faith. In addition, the witness evidence rendered by both parties shows cooperation and genuine efforts by government officials to resolve the difficulties."

43. Notably, however, the Tribunal did not accept that the 1997 civil unrest could excuse Venezuela's non-performance under the contract by reason of force majeure. Three cumulative requirements are necessary for the application of the principle of force majeure: (i) performance under the contract must be rendered impossible; (ii) the event giving rise to impossibility of performance must be unforeseeable and; (iii) the event must not be attributable to the party seeking to invoke the principle. Pointing to unrelated violent public protests which erupted in 1989 resulting in the death of 300 people and substantial property damage, and pointing to the impact of this event on "Venezuelan society in general and on the political system in particular" ${ }^{34}$ the Tribunal concluded the 1997 unrest and resulting impossibility of raising the toll rates could not be considered unforeseeable at the time of negotiation of the Concession Agreement. ${ }^{35}$

44. During the quantum phase, the Tribunal allowed certain claims for out-of-pocket expenses incurred by the Claimant; the major issue, however, related to the question of lost profits. The Tribunal first noted a reluctance in arbitral jurisprudence to award lost profits where work under the contract remained unperformed. In this respect the Tribunal considered it significant that the main objective of the highway project, construction of the Bridge, had not been achieved nor had other aspects of the Concession Agreement been fulfilled such as works on the alternate route. Non-construction of the Bridge was also relevant in the Tribunal's conclusion that the claim for lost profits was too speculative in nature to satisfy the legal requirements for recovery under this banner. In his respect, it was also important that the Tribunal was not convinced by the Claimants evidence of lost profits.

45. Finally, the Tribunal was of the opinion that the contract contained mechanisms, such as the minimum guaranteed income provision, which could remedy any harm suffered by the Concessionaire in the event of breach of contract by Venezuela. Accordingly, remediable harm could only have occurred if and when such mechanisms failed or were not available. As such, the time of harm, and thus the proper date of valuation of the claim, was the date on which the Claimant terminated the contract. As previously mentioned, however, the Tribunal was not convinced by evidence put forward by the claimant to base a claim for lost profits. The claim for lost profits was rejected in its entirety. The final award of the Tribunal awarded the claimants damages in the region of 2 billion bolivars plus interest, or approximately $10 \%$ of the relief requested.

46. The highway rehabilitation project has since been reopened and awarded to a Venezuelan construction company. The project has been awarded 182 billion Venezuelan bolivars from the Ministry of Infrastructure. ${ }^{36}$

Bayindir Insaat Turizm Ticaret Ve Sanayi A.S. v Pakistan, Decision on Jurisdiction, 14 November 2005 (ICSID Case No. ARB/03/29). The dispute relates to the consequences of late handover of land to

\footnotetext{
34. At para. 115 .

35. The Tribunal declined to determine the issue of impossibility and attributability, see paras. 120-129.

36. Caracas-La Guaira highway bidding delayed 3-4 months, Business News Americas, May 232003 ; Precomprimidos to being work on US\$70 million bridge, Business News Americas, August 242005 ; Venezuela approves \$70.4 million for Caracas- La Guaira Motorway, Latin American News Digest, August 25 2005).
} 
the contractor. The Tribunal has asserted jurisdiction over the claims, a decision on the merits is pending.

47. In 1993 the Pakistani National Highway Authority ("NHA") entered into a construction contract with the Claimant, a Turkish incorporated entity, for the construction of the Pakistan Isla mabadPeshawar Motorway. Disputes arose under this contract but were amicably settled by the parties in 1997; as part of the settlement agreement new contractual relations were entered into by the parties which incorporated the terms of the 1993 contract. Under the terms of the contract, the works were to be supervised by an Engineer.

48. In January 2001 the Claimant submitted a request to the Engineer for an extension of time, arguing delays in construction were due to the conduct of Pakistan including late hand-over of land. In April 2001, before the Engineer delivered his decision on the requested time extension, the NHA informed the Claimant that "liquidated damages would be imposed on Bayindir for late completion..." Four days later the NHA served a Notice of Termination of Contract upon the Claimant and requiring the Claimant to hand-over the site to the NHA. "Thereafter, the Pakistani army surrounded the site and Bayindir's personnel were evacuated." In December 2002 a contract for the completion of the works was awarded to a third party. In April 2002 the Claimant initiated ICSID arbitration under the 1995 Turkey-Pakistan BIT, alleging, inter alia, expropriation and breaches of fair and equitable treatment, national treatment and most favoured nation treatment (MFN).

49. In respect of the MFN claim, the Tribunal concluded that the broad wording of the relevant clause did not limit their examination to "regulatory treatment" but rather extended to actual treatment accorded to the investor. At heart of the national treatment and MFN claims is the allegation that Pakistan acted for reasons of local favouritism and to reduce the project costs. Insofar as the BIT does not contain a clause on fair and equitable treatment, the Tribunal has asserted the operation of an MFN provision prima facie obliges the Respondent to treat the Claimant fairly and equitably. The underlying arguments supporting this allegation are (i) that Pakistan failed to provide a stable framework for its investment through changes in general policy towards the investment and; (ii) that the expulsion of the Claimant was motivated by local protectionism. On the other hand, the Tribunal has rejected arguments that standards of due process were breached insofar as the Claimant had not exhausted domestic remedies and no evidence had been put forward to support the allegation of lack of independence of the domestic judiciary.

50. The claim of expropriation, for its part, involves two elements: (i) alleged expropriation of contractual rights and; (ii) retention of equipment following the expulsion. While the parties agreed that taking of contractual rights can only amount to an expropriation where the measure was taken in the exercise of sovereign powers, the Tribunal found it "difficult to rule out puissance publique upon a prima facie analysis at the jurisdictional stage" and accordingly has reserved judgement on this matter for the merits stage.

Hussein Nuaman Soufraki v The United Arab Emirates, Decision on Jurisdiction 7 July 2004 (ICSID Case No ARB/02/7). The dispute in this case arose in relation to a 30 year Concession Agreement between the parties under which Mr. Soufraki undertook to develop, manage and operate the Port of Al Hamiriya. The Tribunal, however, denied jurisdiction to hear the dispute as it found the Claimant did not satisfy the nationality requirement under the BIT invoked.

- $\quad$ Cases pending 
- ADC Affiliate Limited and ADC \& ADMC Management Limited v. Republic of Hungary (ICSID Case No. ARB/03/16) Airport project, Decision pending

- Fraport AG Frankfurt Airport Services Worldwide v. Republic of the Philippines (ICSID Case No. ARB/03/25) Construction of an airport terminal, Decision pending

- Compagnie d'Exploitation du Chemin de Fer Transgabonais v. Republic of Gabon (ICSID Case No. ARB/04/5) Railway concession agreement, Decision pending

- Desert Line Projects LLC v. Republic of Yemen (ICSID Case No. ARB/05/17) Road construction contract, Tribunal not yet constituted

Water and sanitation

Compañia de Aguas del Aconquija, S.A. \& Compagnie Générale des Eaux v The Argentine Republic, Award 21 November 2000, Decision on Annulment 3 July 2002, (ICSID Case No. ARB/97/3 commonly referred to as Vivendi $v$ Argentina). This dispute relates to a water and sewage concession contract; the Claimants alleged the provincial authorities had interfered with performance of the concession while the authorities alleged the Claimants had not fulfilled their obligations under the contract. While a Decision was rendered by an arbitral tribunal, this Decision has been annulled and a new tribunal will be constituted to re-hear the merits of the dispute.

51. The dispute in the present case does not arise directly out of the Argentine Financial Crisis, rather it relates to a dispute which arose prior to the financial crisis between the Claimant and the Provincial Government of Tucumán in Argentina. In 1993 the provincial government decided to privatize its water and sewage facilities that were until then operated by the provincial authorities. This decision to seek private investment did, however, coincide with economic reforms and liberalizations that were taking place at the national level since 1989. In 1995 the provincial government entered into a 30 year Concession Contract with Compagnie Générale des Eaux (CGE) and its Argentine affiliate (Compañia de Aguas del Aconquija) under which the claimant assumed responsibility for operation of water and sewage facilities within the province.

52. Conclusion of the Concession Contract occurred only after lengthy negotiations between the parties with respect to, inter alia, tariffs under the contract and the investment CGE would need to make to expand and improve an "inadequate and antiquated infrastructure". ${ }^{37}$ From an early stage, however, disputes arose between the parties to the Concession Contract whereby each alleged the other party had failed to meet its commitments under the contract. In the ICSID arbitral proceedings, the Claimant alleged it was subjected to harassment and obstruction by the provincial authorities, including encouraging CGE's customers not to pay their bills. The claimant suggested these obstructive policies were the result of the local government attempting to seek approval of the local residents. While the parties to the Concession Contract attempted to find a negotiated agreement, these negotiations ultimately failed.

53. In August 1997 CGE informed the provincial government it was rescinding the Concession Contract by reason of Tucumán's breach of obligation. The provincial authorities rejected CGE's notice of rescission and in September 1997 terminated the Concession Contract. Pursuant to stipulations under

37. At para. 28 . 
the Concession Contract, however, the province considered CGE to be under an obligation to continue to perform water provision and sewage services for a period of 18 months or until a successor operator was established. Although the claimant contested this interpretation of its obligations, it nevertheless continued to provide these services for a period of 10 months after which point a national governmental agency assumed responsibility for these services.

54. The Government of Argentina has resisted the claim raised against it by CGE. In particular, it argued that the claimant had failed to provide services of the requisite standard or made the required infrastructure investments under the Concession Contract; that the issues in dispute are of a purely contractual nature and thus do not arise to the level of an international delict and; that the Federal Government is not responsible in international law for the actions of the provincial authorities. In its Award, the Tribunal considered it had jurisdiction to hear claims based on the France-Argentina BIT however insofar as the claims were intertwined with the Concession Contract and this latter Contract had conferred jurisdiction on the domestic courts, the Tribunal dismissed the claims. This Decision, however, was subjected to an annulment procedure the result of which was to confer jurisdiction on a tribunal to hear claims arising out of breach of contract insofar as they also amount to breaches of the BIT. A new Tribunal has reportedly since been established to re-hear the claim. ${ }^{38}$

The Biwater Dispute. ${ }^{39}$ (Biwater Gauff (Tanzania) Limited v. United Re public of Tanzania ICSID Case No. ARB/05/22). The Biwater dispute arose in relation to provision of water and sewage services in Dar es Salaam. The concession contract has been rescinded by governmental authorities on the grounds that the required infrastructure investments had not taken place and the quality of service had deteriorated. This dispute has recently been registered with ICSID.

55. Water resources in Tanzania are reputed to be sufficient to meet demand. However, distribution has reportedly been sub-standard due to inadequate and antiquated infrastructure. In Dar es Salaam these problems are compounded by the fact the existing pipe network, originally built in the 1950's, is grossly insufficient to provide water to the burgeoning population. ${ }^{40}$ Privatisation of the Dar es Salaam Water and Sewage Authority (DAWASA) came as a result of the imposition of pre-conditions to qualification

38. Reported in Petersen, INVEST-SD: Investment Law and Policy Weekly News Bulletin, 11 May 2004.

39. See e.g. City Water and the Government of Tanzania, Biwater Press Release 01/06/2005; Dar Water Supply Now for Privatisation, Africa News February 2, 2000; Dar es Salaam Upbeat About Water Supply in View of Privatisation, Pan African News Agency August 6, 2002; British, German firms to run Tanzanian water utility, Agence France Presse December 17, 2002; Major Dar Water to Start Mid-July, Africa News April 11, 2003; Pipes Run Dry in Tanzania, The Guardian (London) September 27, 2004; Government Terminates Firm's Water Contract, Africa News May 17, 2005; Aid to Africa: Flagship water privatisation fails in Tanzania: UK firm's contract cancelled amid row over supply, The Guardian (London) May 25, 2005.

40. "Most sewerage systems in the country are dilapidated due to years of neglect caused by lack of foreign currency to import spare parts. The situation has been worsened by the rapidly increasing population. 'The problem of water in Dar es Salaam is mainly caused by population growth. The current infrastructure was meant to serve not more than a million people; today there are more than over two million people in Dar es Salaam. It's evident that the current system is over-stretched,' said Dar es Salaam Regional Commissioner Yussuf Makamba. The Dar es Salaam Water and Sewerage Authority (Dawasa) can supply 60 million gallons of clean water per day, which falls far short of the 90 million gallons needed daily by the city." Government Moves to Privatise Water Supply, Africa News June 23, 2003. 
for the Highly Indebted Poor Countries initiative of the World Bank and IMF. These financial institutions, in conjunction with the African Development Bank and the European Development Bank undertook to co-finance the majority of the water supply and sanitation project. The operator ultimately chosen, after a competitive bid, to run DAWASA was a joint venture comprising of Biwater, Gauff International of Germany and a Tanzanian enterprise. The joint venture took the name City Water Services.

56. A ten year contract was entered into by the private investor and the governmental authorities under which City Water undertook to invest US\$8 million in the first two years of the contract in improving and expanding the Dar es Salaam water and sewage infrastructure. Two years into the contract, however, governmental authorities purported to cancel the contract. Tanzania alleges the quality of water had deteriorated since City Water assumed responsibility under the contract and that of the $\$ 8$ million promised, only $\$ 4.1$ million had been invested and none of this investment had gone to installation of new pipes. City Water, for its part, argues any delays were not directly caused by it, that the government had given it erroneous data regarding water supplies and levels of non-payment by customers and that the government could not unilaterally terminate the contract in the circumstances of the case. In short, both parties allege breach of contract.

57. Tanzania has also deported three of City Water's top executives. This dispute has been submitted to international arbitration. In addition, this dispute has raised concerns within the international community in relation to the manner in which development funds are disbursed within developing countries. A number of NGO's have further criticised the 'imposition' of privatisation by the World Bank and IMF. On November 2, 2005 ICSID registered a claim by Biwater Gauff (Tanzania) Limited against Tanzania. ${ }^{41}$

Aguas del Tunari, S.A. v Republic of Bolivia, Decision on Jurisdiction, 21 October 2005, ICSID Case No ARB/O2/3. The dispute arose as public resistance to the concession terms made the Bolivian authorities rescind the contract. The Tribunal has asserted jurisdiction over the claim, a decision on the merits is pending.

58. As part of a privatisation programme, the government of Bolivia sought to award a Concession contract to provide water and sewage facilities for the city of Cochabamba and an electricity generation licence to a private participant. After an unsuccessful international tender process, Bolivia was approached by and entered into negotiations with a consortium regarding the Concession area. These negotiations were successful and in September 1999 the Bolivian Water Superintendence entered into a 40-year Concession with the Claimant, a locally incorporated entity established as a vehicle for the consortium's investment. Under the terms of the Concession, the Claimant was to "provide a regular volume of drinkable water of a certain quality in exchange for a negotiated return on its investment."

41. Biwater has also been party to a settlement agreement, entered into with the government of Belize, which ended its involvement in a privatis ed water utility. Biwater had entered Belize with a Dutch partner through acquisition of the State's 82\% shareholding in Belize Water Services (BWS). Subsequent to this purchase, BWS requested the regulatory authority to increase tariffs to cover existing debts and other losses. This request was rejected, reportedly on the grounds the authority was not convinced lower income customers could afford a price increase; the investors' initiated arbitration against Belize. In a settlement agreement, Belize re-purchased the $82 \%$ shareholding at its original purchase price which will be re-paid in instalments. See: Petersen, Investment Treaty News October 26, 2005 'Belize dodges water suit with UK firm, but arbitration still an option in Tanzania". 
Concerns relating to an apparent lack of transparency in the negotiation process and potential rate increases led to public opposition of the Concession. The Claimant began operations in January 2000. However, in the face of violent public protest Bolivia rescinded the Concession in April 2000. In November 2001 the Claimant initiated ICSID arbitration under the Netherlands-Bolivia BIT, asserting several breaches of the substantive protections of that instrument.

\section{4) Power generation and distribution}

Mihaly International Corporation v Democratic Socialist Republic of Sri Lanka Award 15 March 2002 (ICSID Case No. ARB/O0/2). Mihaly International is notable in that it is the only known case to deal with the question of pre-investment expenditures.

59. In 1992 the government of Sri Lanka sought to develop a 300MW thermal power station on a build own transfer (BOT) basis. Mihaly International's (USA) competitive tender was accepted and the two parties entered into a period of negotiation. These negotiations, however, never matured into a contract. The arbitration brought before ICSID was an attempt by Mihaly's to recover its pre-investment expenditures; the Tribunal, however, found it had no jurisdiction to hear these claims as, in the absence of a contract, these expenditures did not fall within the meaning of "investment" for the purposes of the ICSID Convention or under the relevant BIT.

Himpurna California Energy Ltd. v PT (Persero) Perusahaan Listruik Negara (Indonesia), Final Award of 4 May $1999 .{ }^{42}$ The dispute in this case arose in the context of the Asian financial crisis and related to measures taken by the Indonesian government which effectively terminated the Claimant's Concession Contract. The governmental authorities were held liable by the Tribunal for damages although, notably, the pecuniary award was far less than the relief requested.

60. In 1994 Himpurna California Energy Ltd. and Patuha Power Ltd, both subsidiaries of a US enterprise, entered into contracts with the Indonesian state electricity corporation PT (Persero) Perusahaan Listruik Negara (PLN) to develop and exploit geothermal resources. Under the terms of the contracts Himpurna California Energy and Patuha Power would develop a number of geothermal fields; PLN would purchase in US dollars the total output capacity for a period of 30 years. The contracts also provided for ad hoc arbitration under the UNCITRAL Rules in the event of a dispute between the parties. $^{43}$

61. As a consequence of the 1997/98 Asian financial crisis, PLN encountered difficulties in meeting its US dollar obligations and defaulted on payments due to the Claimant. PLN estimated its losses under the contracts with Himpurna California and Patuha Power to be in the region of US\$19.9 billion. ${ }^{44}$ At this juncture, one of Himpurna California's sites was operational while the remaining sites were still in development. In its request for arbitration, the claimants sought relief in excess of 25 billion bolivars for out-of-pocket expenses, lost profits and interest thereon. In September 1997 Indonesia issued a Presidential Decree directed towards a large number of infrastructure projects and which

42. Himpurna California Energy Ltd. (Bermuda) v PT. (Persero) Persusahaan Listruik Negara (Indonesia), Final Award of 4 May 1999, reported in 14 Mealey's International Arbitration Report pp. A-1 - A-58; An identical award was rendered in the claim raised by Patuha Power.

43. At paras. 10-17.

44. At para. 24. 
effectively suspended the Claimant's contract. After unsuccessful attempts to initiate negotiations with PLN, the Claimant shut down its operational site, ceased all development and construction activities and in August 1998 initiated arbitration against the Respondent.

62. PLN attempted to avoid its contractual liability on a number of grounds including, inter alia, operation of the doctrine of force majeure and changed circumstances. These arguments were not accepted by the Tribunal. The question of force majeure turned on attribution of the PLN's conduct to the state. If the PLN was not considered independent of the state, it could avoid all contractual liability through operation of the doctrine of force majeure as its conduct would be considered as imposed by the State. On the facts, however, the Tribunal found the conduct of the PLN to be attributable to Indonesia under the principles of State Responsibility. As the Decree was an act of state and the PLN was an organ of the state, it was not open to the PLN to avoid its contractual liability through operation of the doctrine of force majeure.

63. PLN also attempted to argue that the changed circumstances brought about by the financial crisis warranted review or renegotiation of the contract. The Tribunal, however, considered the contract to have explicitly placed the risk of depreciation of the local currency on the PLN. The Tribunal continued: "The fact that the Indonesian currency has suffered a painfully acute depreciation cannot be accepted as a basis for concluding that somehow PLN's dollar-denominated obligations must be renegotiated on some undefined but overriding basis. The immediate answer to such a contention is that the reason for the dollar-denominated payment obligations was precisely to allocate the risk of major currency movements."

64. The request for arbitration claimed recovery of US $\$ 2.3$ billion in damages, ${ }^{45}$ reflecting wasted costs and lost profits. ${ }^{46}$ However, in a somewhat controversial decision the Tribunal applied the doctrine of abuse of rights and reduced the amount awarded to the Claimant to US\$527 million.

65. Indonesia had entered into similar Power Purchase Agreements with approximately 26 other independent power producers (IPPs). In at least one other instance, arbitration was initiated; while that claim was successful, enforcing the award remained problematic for the investor. ${ }^{47}$ A certain number of these IPPs received compensation from international political risk insurance institutions, leading to claims by these institutions against Indonesia. In at least one instance OPIC and Indonesia reached agreement on a repayment schedule for the US\$290 million claim. ${ }^{48}$ Many other IPPs also raised claims in the domestic courts or initiated arbitration. In 2002, the Indonesian Government announced it had successfully renegotiated most of the existing contracts with IPPs or entered into interim agreements under which the power purchase price was to be reduced. It is not clear whether the IPPs agreed to terminate their claims for compensation. ${ }^{49}$ In the same year Indonesia enacted legislation under which the energy distribution market would be opened to IPPs, thus ending PLN's monopoly in this area.

\footnotetext{
45. The Patuha claim sought to recover US\$1.4 billion in damages.

46. At para. 234 .

47. Karaha Bodas v. Perusahaan Pertambangan \& Pt. Pln, Final Award, December 18, 2000.

48. Government Agrees to Pay OPIC US\$290 million Claim, The Jakarta Post October 12, 2000.

49. Indonesia regulations: New laws, accords aim to revive power sector, The Economist 11 October, 2002.
} 
66. The Thai energy market was also affected by the financial crisis but did not give rise to the same number of disputes as in the case of Indonesia. Thailand had several contracts with IPP's, however, these contracts departed from industry norms in that the energy purchase price was not pegged to the US dollar. At the time of contracting, this policy measure was accepted due to the "stable relationship between the Thai Baht and the US dollar". ${ }^{50}$ Following the collapse of the Baht these contracts required re-negotiation in order to remain financially viable. Under the re-negotiated contract, currency exchange risk would be shared between the State and the IPPs. ${ }^{51}$

Tanzania Electric Supply Company Limited (TANESCO) v Independent Power Tanzania Limited (IPTL), Final Award 12July 2001 (ICSID Case No. ARB/98/8). The dispute in th is case is notable in at least two particular ways. First, in contrast to the majority of investor-state disputes, the investor, not the host state or agency, was the Respondent. Second, the final award rendered by the Tribunal marks a divergence from the majority of international foreign investment arbitration awards insofar as it embodies a non-pecuniary award.

67. The background to the contractual relationship between the parties is described as "a severe shortage of electric power within Tanzania which was apparently due in part to developments in the economy which stimulated significant growth in the demand for electricity, coupled with problems experienced within Tanzania's existing hydro-generated power system." TANESCO is a state corporation "charged with responsibility for the generation, supply and transmission of electric power throughout the country." TANESCO and IPTL entered into a Power Purchase Agreement "whereby IPTL agreed to design, construct, own, operate and maintain an electricity generating facility... and to operate the Facility and deliver electricity generated thereby to TANESCO for an initial period of 20 years." Payment of the tariff under this Agreement was to be adjusted to account for capital costs, debts incurred, maintenance costs and fuel costs. As a condition precedent to TANESCO assuming its obligation to purchase electrical energy from the Respondent, IPTL was required to obtain a certificate from an Independent Engineer stating "that the Facility has been designed and constructed in accordance with the terms of the Agreement and the general layout drawings."

68. A dispute arose between the parties and, after negotiations failed to produce an amicable settlement, arbitral proceedings were instituted under the auspices of ICSID. The Tribunal summarized the dispute as follows:

Lengthy delay in the commencement of commercial operations was clearly not in the interest of either party, and the Tribunal concludes that business efficacy requires the implication of a term that the parties shall negotiate in good faith in an endeavour to agree the appropriate adjustment with the minimum of delay. Each party accuses the other of a lack of good faith in this respect. TANESCO asserts that the primary reason for the failure to achieve any progress in the tariff negotiations which took place between about April and September 1998 was the refusal by IPTL to accept that it was under any obligation to incur project costs reasonably and prudently, or to provide TANESCO with documents and other information necessary to demonstrate that project costs (a) had actually been incurred and (b) had been incurred reasonably and prudently. IPTL, on the

50. Asian Currency Crisis Hits IPPs, Financial Times Energy Newsletters: international coal report October 8, 1997; see also Crisis-Hit Thailand Scales Back Gas Growth, Financial Times Energy Newsletters: international gas report August 22, 1997.

51. PTT Set For Take-or-Pay Battle, Financial Times Newsletters, Power in Asia 17 April, 2001. 
other hand, asserts that TANESCO was not prepared to embark upon negotiations in good faith at all, in circumstances where it was alleging that, by reason of the substitution of medium speed for low speed diesel engines, the Facility had not been built in accordance with the contractual description and IPTL was thereby in default

69. The Tribunal further remarked: "These events took place against the background of apparent controversy within Tanzania regarding a competing project... This ival project was to be built by Canadian interests and financed by the International Bank for Reconstruction and Development. There was evidence in the arbitration that, notwithstanding the urgency with which the PPA had been concluded in 1995, pressures were thereafter exerted both on and within the Government of Tanzania and TANESCO to defer it, if not eliminate it, in favour of the SONGAS project. ${ }^{, 52}$

70. In its Awards, the Tribunal concluded that the certificate of compliance from an independent engineer was valid and binding and accordingly IPTL had not failed to fulfil a condition precedent to TANESCO's assumption of obligations under the Agreement. It further held that the Respondent was under an implied obligation to incur costs reasonably and prudently and that it had failed to do so in respect of certain costs incurred. Payment under the Agreement was adjusted accordingly. Importantly, the Tribunal also held the contract between the parties remained valid and binding and could not be unilaterally terminated by one of the parties. As such, the Tribunal considered it appropriate to order the parties to fulfil their obligations under the Agreement and "to use their best endeavours and to co-operate together to achieve the commencement of commercial operations".

PSEG Global Inc, The North American Coal Corporation, and Konya Ilgin Elektrik Üretim ve Ticaret Limited Sirketi $v$ Republic of Turkey, Decision on Jurisdiction 4 June 2004(ICSID Case No ARB/02/5). The present dispute relates to the effective termination of a contract for the construction and development of an electric power plant. The parties disagree as to the terms of the contract and the extent of their obligations that may have arisen under that contract. An ICSID Tribunal has assumed jurisdiction to hear the claim.

71. The background to this case is an energy expansion programme undertaken by Turkey. To achieve its objectives, Turkey amended its regulatory framework to allow for private participation in the energy sector, in particular the amended framework provided for a Build-Operate-Transfer (BOT) model. In April 1994 PSEG entered into negotiations with the Ministry of Energy in relation to a proposed lignite-fired electric power plant. Included in this proposal was the development of an adjacent lignite mine which would provide the plant's fuel requirements. A Feasibility Study was prepared detailing the generating capacity, price and duration of operations. This Study was approved by the relevant authorities and the parties entered into an Implementation Contract. This latter Contract provided for the possibility of additional studies to be carried out in relation to the proposed mine development; further studies by the Claimant in this respect led to a US $\$ 1$ billion increase in the expected costs of the project. To account for this additional cost, the structure of the agreement between the parties would necessarily have to be altered, more specifically through increasing Turkey's capacity purchase obligations.

72. In their pleadings, the parties expressed "different view about what was agreed in this respect." Nevertheless, the domestic authorities approved the Implementation Contract in the form of a

52. The Financial Times reports that "donors and consultants... argued that Tanzania could not afford both schemes...", David White, Controversy is the rule rather than the exception in contracts, Financial Times 3 August, 2005. 
Concession Contract in March 1998. A dispute between the parties persisted as to "whether the [Concession Contract] included a final agreement on key commercial terms and what those terms were..." Further, the parties were not in agreement as to the appropriate corporate structure for implementation of the project, a factor which carries important tax consequences. The Claimant alleges policy changes undertaken in anticipation of accession to the European Union led the Turkish authorities to abandon the BOT model "as it was thought that the profitability of the project would be artificially ensured through government guarantees and other mechanisms, including a subsidized tariff structure resulting in uncompetitive generation costs." These policy changes, according to the Claimant, are at the origin of measures which led to the effective termination of the project and Turkey's action and deliberate inaction to destroy the Claimant's investment.

73. Turkey, for its part, alleges that the dispute between the parties arises "from the project never having moved off the drawing board or the negotiating table." Insofar as the Claimant had underestimated the project costs, Turkey argues the parties never reached agreement on the key commercial terms of the contract. Turkey further argues that "the Claimants have constantly sought to pass on to the Turkish Government and consumer the higher costs involved by selling more electricity" resulting in an increased burden to the public. The Tribunal has assumed jurisdiction to hear the dispute, an award on the merits is pending.

AES Summit Generation Limited v Hungary (ICSID Case No ARB/01/4). ${ }^{53}$ The dispute in the present case relates to non-ratification by the state of a Power Purchase Agreement and the consequences thereof. Ultimately, the parties reached a settlement agreement and the arbitral proceedings were terminated.

74. During the early to mid 1990's, Hungary began to privatise its energy sector. In July 1996 the State monopoly power wholesaler (MVM) entered into a privatisation agreement with AES under which the investor undertook to retrofit an existing plant, cleanup existing environmental damage and invest in the expansion of the domestic energy market through development of a new plant. To fulfil these obligations, AES would incur "stranded costs", i.e. costs incurred in the investment but which would not be economically viable in a liberalised market. As such, under the agreement AES expected to recoup its investment through conclusion of a 20 year power purchase agreement (PPA) under which tariff increases would guarantee AES an $8 \%$ return on assets. The government, however, refused to ratify the PPA; this refusal has been attributed to a number of competing concerns. First, a new government elected in 1998 had demonstrated open hostility to private participation in the energy sector. Second, the MVM had received more competitive tenders for purchase of electricity into the national power grid, both from domestic sources and imports. Finally, the State was in the process of liberalising the energy

53. See e.g. AES seeks arbitration in rift over PPA failure with privatized plant in Hungary, Electric Utility Week November 6, 2000; AES corp. files suit in Hungary to recover \$295 million in damages, Global Power Report 10 November, 2000; Hungary: stranded, The Economist 1 January, 2001; AES in Hungary: a tale of woe, Financial Times 2 March, 2001; MVM wins HUF 32 billion court case against Bakony Power, Interfax News: Hungary business report March 5, 2001; AES sues Hungary as MVM wins Bakony dispute, Financial Times March 22, 2001; Power generator AES looks to close legal disputes with Hungary by summer 2002, feels discrimination, Interfax News: Hungary Business Report July 30, 2001; AES drops lawsuits after signing long-term contract with MVM, MTI Econews December 20, 2001; MVM and AES resolve disputes over Tisza II- 15 year PPA signed, Interfax News: Hungarian Business Report 27 December, 2001; MVM wins suit filed by AES, Financial Times 13 May, 2003; Arbitration court rules in favour of Hungarian state privatisation agency, World Markets Research 3 June, 2003. 
sector to bring the domestic market in line with European Union standards. In 1999 the government declared a moratorium on all long-term PPAs and cancelled all such existing contracts.

75. AES raised three separate arbitrations in respect of these facts. One arbitration related to liability under Hungarian law for the environmental cleanup obligation assumed under the privatisation agreement. The second arbitration similarly concerned questions of domestic law and related to the proposed retrofit and new developments which had not taken place due to MVM's refusal to sign the PPA. The third arbitration alleged breaches of the Energy Charter Treaty and the US-Hungary BIT and international responsibility thereunder. A domestic consortium, Bakony Power Plant, had similarly raised a domestic arbitration in relation to cancellation of its PPA, however, the tribunal in that case rejected the claim and held MVM had not acted in breach of domestic law. By contrast, MVM had paid a German investor US\$30 million in respect of cancelled expansion projects and had entered into a 10 year PPA as part of a settlement with a Belgian investor.

76. By mid-2001, AES was threatening to close two blocks of its operational site if a solution could not be found to the existing dispute. In December 2001 AES and MVM reached agreement and settled their dispute. Under this agreement, MVM entered into a 15 year power purchase agreement and undertook to purchase AES' total capacity. The power purchase price was to be at the regulated price until market liberalisation legislation came into force in 2003 after which point the price would be based on market prices. MVM's stated motive for entering into this agreement despite its previous position was to ensure a stable supply of energy produced in the domestic market. Under a separate agreement, AES undertook to drop its arbitral claims with the exception of the question of environmental liability. An arbitral tribunal ultimately rejected this latter claim, finding MVM had no outstanding liability.

The Dabhol Power Project. ${ }^{54}$ Several disputes arose in connection with an energy production plant, the Dabhol Power Project. The majority of these disputes related to non-payment under the contract by a state agency and refusal by the central government to honour guarantees made in connection with the project. A series of arbitrations were raised against the state agency, resulting in pecuniary awards to the Claimants. Settlement agreements were also entered into with the State of India, bringing an end to the disputes.

77. In early 1995, a consortium led by Enron entered into a contractual arrangement with the Maharashtra State Electricity Board (MSEB) in India for the construction and operation of an electrical power plant, the Dabhol Power Project. This project was widely seen as the flagship of the liberalisation

54. See e.g. Petersen, Bechtel subsidiary wins arbitration with Indian State of Maharashtra, Investment Law and Policy News Bulletin 5 May, 2005; Energy in India, The Economist 27 May, 2005; A tale of two projects, Financial Times 1 June, 1995; Life After Death at Dabhol, Modern Power System 31 May, 1999; New Threat to Dabhol Project, Financial Times 12 December, 2000; India-Project, Financial Times (US ed.) 13 January, 2001; Crunch for India private power as Dabhol calls on guarantees, Financial Times International Gas Report 2 February, 2001; Enron Dispute Heading for Court, Financial Times 9 April, 2001; Enron, and on, and on, The Economist April 21, 2001; Dabhol Returns Centre Stage, Financial Times May 9, 2001; Enron says “no” to Dabhol renegotiation, Financial Times May 15, 2001; Work stopped on Indian power plant, Financial Times June 18, 2001; Enron files claim for Dabhol losses, Financial Times December 21, 2001; GE and Bechtel buy stake in Dabhol, Financial Times April 14, 2004; Hope in Sight for Dabhol Project, Financial Times February 7, 2005; GE settles dispute with India's MSEB on Dahbol power project, AFX News July 4, 2005; Dabhol Resolution, Modern Power System August 9, 2005; New Delhi Hopes to Kick Start Dabhol, Modern Power System October 12, 2005. 
programme to open domestic markets to foreign direct investment, in particular in the energy sector where heavy investment was needed to meet demand requirements. The contractual terms entered into included the creation of a corporate vehicle, the Dabhol Power Corporation (DPC), which would construct the power plant in two phases and sell its power to the MSEB who would then distribute the energy within the state. Enron was the majority shareholder in the DPC, with General Electric and Bechtel each owning a $10 \%$ stake.

78. The Power Purchase Agreement (PPA) took the form of a 'take or pay' contract, in other words the MSEB was obliged to purchase the total power capacity irrespective of the amount of energy actually used. The energy purchase price was agreed to be adjusted to cover, inter alia, construction costs and fuel input costs. This contractual arrangement was to be in force for a period of 20 years and was backed up by a guarantee issued by the State government and a counter-guarantee by the Federal government. Authorisation of the project and conclusion of the contract occurred in the context of "fast-track" projects, a federal initiative designed to attract foreign investment through measures including the issuance of governmental guarantees. Further, these projects were initiated on the basis of individual negotiations rather than public tender. This initiative was short-lived due to public opposition to what was seen as overly generous terms; the Dabhol Power Project was the only project to be started under this initiative.

79. Shortly after conclusion of the contract and commencement of construction, the Project became the object of considerable controversy. Public opinion strongly opposed the Project on the ground that the energy purchase price was allegedly considerably higher than that of other power producers. ${ }^{55}$ State elections had also brought about a change in the governing party; the incumbent party had consistently shown strong opposition to the Project and in 1995 it suspended the Agreement. A renegotiated PPA was, however, concluded in 1996 under which the energy purchase price was reduced and MSEB was obliged to purchase a portion of Enron's interest in the Project. This notwithstanding, the Project continued to be opposed both at the political level and by the public.

80. Phase I of the Project was completed and the DPC began delivering electricity under the contract. By late 2000 and early 2001, however, the MSEB had defaulted on several monthly payments. As with many other State electricity boards, the MSEB had long-standing financial difficulties arising from heavy subsidisation of energy to the agricultural industry and rural communities, piracy and nonpayment of bills by its consumers. In this respect it is noteworthy that prior to financial close of the Project, the World Bank had refused funding as it was not convinced the MSEB could meet its financial obligations given the high energy purchase price under the PPA. In an attempt to justify non-payment under the PPA, the MSEB claimed the DPC had breached certain technical provisions of the contract. After continued non-payment the DPC attempted to call in their guarantees, however, the Federal government refused to make such payment until a price had been negotiated to reflect DPC's alleged technical breach.

81. In June 2001 construction of Phase II was halted after lending institutions financing the Project refused further disbursement of funds given this payment dispute. Enron initiated arbitration and took the first steps necessary to bring the Project to a close. News reports indicate a willingness on the part of the Indian government to enter into negotiations as failure of the Project was seen to have a negative

55. Whether these allegations were in fact true is, at least, debatable. Existing power plants had entered into different financial arrangements under which, unlike the Dahbol Project, construction costs were not reflected in the energy purchase price but were accounted for by other means. 
impact on foreign direct investment flows insofar as potential future investors would perceive India as having a high political risk and be seen as not honouring its contractual obligations. Whatever negotiations might have taken place never matured into a settlement agreement and Enron pursued its arbitral claim. The private investors also petitioned OPIC for compensation for India's allegedly expropriatory measures and were awarded compensation in 2003. The situation was further complicated in late 2001 when Enron entered into bankruptcy proceedings.

82. Ultimately in April 2004, in an agreement engineered by OPIC, Enron's 65\% shareholding was purchased by its previous partners, GE and Bechtel. These two corporations also initiated arbitrations against India in an attempt to recoup their losses under the investment. Despite non-cooperation by the Indian authorities in the arbitral process, Bechtel was successful in its claims against the State of Maharashtra and the MSEB and is reported to have been awarded US\$125 million. Related claims were raised by Bechtel against the State of India; these claims were subsequently dropped pursuant to a settlement agreement under which the company was reported to have received US\$160 million. GE also entered into a settlement agreement with the State of India under which it terminated arbitral proceedings against the government and was granted financial remuneration for losses sustained. In July 2005 GE and Bechtel sold their stakes in the Dabhol Power Project to two Indian agencies; fiscal concessions were granted by the central government to the DPC as part of a rescue package to bring the Project back into production.

\section{i. $\quad$ The Energy Charter cases}

Nykomb Synergetics Technology Holding AB v The Republic of Latvia, Award 16 December 2003 SCC Case No. 118/2003. The dispute in the present case has as its source a disagreement as to the appropriate tariff applicable under a contract for the production of energy. The Tribunal awarded pecuniary damages to the Claimant and specified the future tariff payable under the contract.

83. During the mid-90s the Latvian government sought to diversify its energy supply sources and to encourage use of cleaner fuels through private investment in the energy sector. Low prices had made this market unattractive to private investors; in order to attract investment, the Latvian government enacted the "Entrepreneurial Law" of 1995 under which electricity was "to be purchased into the national power transmission grid at a price twice as high as the average consumer price, i.e. the double tariff" for a period of eight years. ${ }^{56}$

84. Latvenergo is, under the laws of Latvia, the sole distributor of electricity through the national grid and as such is the sole purchaser of electricity produced by the private sector. In 1996 Windau, a locally incorporated enterprise, entered into contracts with Latvenergo to build 16 cogeneration plants, i.e. plants capable of producing both electricity and heat. Under the contracts, Latvenergo undertook to purchase any energy surplus to Windau's own production requirements at a price stipulated by law. Subsequently, a law amendment was enacted excluding the double tariff for plants with contracts effective after 31 May 1997. ${ }^{57}$ Windau completed construction of "Bauska plant" in September 1999 but did not deliver electricity to Latvenergo until February 2000 as a dispute arose regarding the correct purchase price. Windau claimed contractual entitlement to the double tariff while Latvenergo claimed the correct multiplier was 0.75 as stipulated by the law amendment of 1997 . Windau began delivery of

$\begin{array}{ll}56 . & \text { At } 3.1 . \\ 57 . & \text { At } 3.3 .\end{array}$


electricity in 2000 at the 0.75 multiplier pursuant to an interim agreement between the parties, however, construction of Windau's other cogeneration plants ceased until such time as the price dispute was finally resolved. While this dispute was ongoing, Nykomb, a Swedish enterprise, purchased $100 \%$ of the share capital in Windau, making it a wholly owned subsidiary of Nykomb. ${ }^{58}$

85. After failing to reach an amicable settlement, Nykomb instituted arbitral proceedings at the Stockholm Chamber of Commerce pursuant to the Energy Charter Treaty 1994 (the ECT). Insofar as the contracts stipulated the purchase price was to be in accordance with the law, the Tribunal had to determine whether the correct purchase price was that in existence at the time of conclusion of the contracts, i.e. the double tariff under the Entrepreneurial Law, or the lesser multiplier established in the 1997 amendment. Here, the Tribunal referred to a decision rendered by the Latvian Supreme Court in a case arising from the same factual circumstances, the Latelektro-Gulbene case, which established that the price clauses in the contracts were to be interpreted as "fixing the multiplier in effect at the moment of signing the contract." ${ }^{, 59}$ The Tribunal considered Latvenergo's obligation under the contracts was to pay the double tariff.

86. In order for the Nykomb's claims to succeed it was also necessary to established whether Latvia incurred international responsibility for the conduct of Latvenergo. The Tribunal concluded state responsibility of Latvia had been incurred under three separate banners. In the first place, the Tribunal held Latvia directly responsible for withdrawal of Windau's statutory right to the double tariff through subsequent legislative acts. Second, the Tribunal considered Windau's contractual entitlement to the double tariff would have been clear subsequent to the Latelektro-Gulbene case. Latvenergo's continued non-payment of the double tariff and the central government's knowledge of this fact enabled the Tribunal to conclude that Latvia failed to take the steps necessary to protect Windau's contractual rights. Finally, the Tribunal considered the legal framework giving life to Latvenergo and its absence of commercial independence determinative of attribution of state responsibility for Latvenergo's conduct. ${ }^{60}$

87. Latvia attempted to argue that as Nykomb was aware of the price dispute prior to making its investment, the Claimant undertook a purely commercial risk which would fall outside the protections of the ECT. While the Tribunal agreed Nykomb must have been aware of the price dispute, it nevertheless found that Nykomb had made its investment in reliance on Windau's contractual right to the double tariff. "Generally, a Contracting Party to the Treaty cannot be relieved of its obligations under the Treaty simply by letting it be announced that legally binding commitments, upon which the foreign investor is relying, will not be honoured". ${ }^{61}$

88. Having thus established that Latvenergo's refusal to pay the double tariff was in breach of its contractual obligations and that this breach invoked the responsibility of the State under the ECT, the Tribunal then had to consider the quantum of damages. While direct loss to Windau could be more easily established, quantifying the "indirect loss" to Nykomb by reduction in the value of its investment was a more difficult. Ultimately, the Tribunal awarded Nykomb the loss of electricity production during the 'dead-lock' period up to the date of the award minus the cost of natural gas required for production. With regard to future profits, the Tribunal considered this too uncertain and speculative to form the basis

58. At 1.1, 3.3 and 3.4.

59. At 3.7.

60. At 4.2 .

61. At 4.3 .3 (c). 
for a monetary compensation, however, the Tribunal ordered Latvia to observe its double tariff obligation for the remainder of the eight year period.

Plama Consortium Limited v Republic of Bulgaria, Decision on Jurisdiction 8 February 2005 (ICSID Case No. ARB/03/24). The claim in this case relates to the conduct of governmental authorities in relation to the Claimant's oil refinery business. In this Decision on Jurisdiction, the Tribunal affirmed its jurisdiction to hear the claims raised by the Claimant.

89. The Claimant, among other things, "alleges that the Bulgarian government, the national legislative and judicial authorities and other public authorities and agencies deliberately created numerous grave problems for Nova Plama and/or refused or unreasonably delayed the adoption of adequate corrective measures". ${ }^{2}$ "Nova Plama is a locally incorporated enterprise in which the Claimant holds a 96.78 per cent share ownership. Nova Plama's business includes a refinery with a "lubricants manufacturing unit... Nova Plama also has its own power plant with a capacity for sales of excess electric power to the local grid". A decision on the merits of these claims is pending.

Petrobart Limited v The Kyrgyz Republic, Award of 29 March 2005 SCC Case. No 126/2003. The dispute in this case relates to interference by the State in the Claimant's ability to enforce payments due under a contract entered into with a State agency. The conduct of the state was held to be in violation of investment protection provisions under the Energy Charter Treaty and as consequence was ordered to pay pecuniary damages to the Claimant.

90. In February 1998 Petrobart, a company incorporated under the laws of Gibraltar, entered into a contract with the State joint stock company Kyrgyzasmunaizat (KGM) for the supply and sale of gas condensate. A specified quantity of gas condensate was to be delivered by Petrobart over a one year period on a monthly basis; payment by KGM was fixed in US dollars. Petrobart delivered the gas condensate under the contract for two months, however, only two of the five invoices generated were paid by KGM. Following non-payment for the delivered quantity of gas condensate, Petrobart ceased to deliver under the terms of the contract but did not rescind or otherwise indicate its understanding that the contract was no longer in effect between the contracting parties. After a period of continued nonpayment, Petrobart initiated judicial proceedings to enforce payment. While the action was successful, KGM's accounts did not contain sufficient funds to cover its debt to Petrobart.

91. An order of seizure against KGM's other assets was obtained from the courts, however, following a letter from the Vice Prime Minister, the court ordered a stay of execution for a period of three months, ostensibly in order to allow the government to take steps to cure KGM's insolvency. Before expiry of this three month period and by Presidential Decree KGM's assets were transferred or leased to two newly created state companies charged with supply of oil and gas within the territory of the State. None of KGM's debts or liabilities was transferred with the result that KGM entered into bankruptcy proceedings and Petrobart's award for payment became unenforceable.

92. Two aspects of the Kyrgyz Republic's conduct were raised before the Arbitral Tribunal established under the ECT: (i) the transfer of assets from KGM to other entities to the detriment of KGM's creditors and; (ii) intervention in judicial proceedings regarding stay of execution of a final judgement. ${ }^{63}$ While the Tribunal considered restructuring of the system for the supply of oil and gas may

$\begin{array}{ll}\text { 62. } & \text { At } 21 . \\ \text { 63. } & \text { At p. } 76 .\end{array}$


have been a legitimate action, it dso held that the state "was under an obligation to carry out this reorganisation in a way which showed due respect for investors. ${ }^{, 64}$ With regards to the letter by the Vice Prime Minister seeking a stay of enforcement of the court award in favour of Petrobart, the Tribunal stated: "The Arbitral Tribunal considers that such Government intervention in judicial proceedings is not in conformity with the rule of law in a democratic society and that it shows a lack of respect for Petrobart's rights as an investor having an investment under the Treaty". ${ }^{65}$ The Tribunal found the Kyrgyz Republic acted in breach of its obligation to accord fair and equitable treatment to investments and to ensure that its "domestic law provides effective means for the assertion of claims and the enforcement of rights with respect to investments". 66

93. The Tribunal was also faced with the question of quantum of damages necessary to place the investor in the situation it would have been in but for the treaty breaches given that KGM had been insolvent and unable to meet the entirety of its debt to Petrobart. In this respect, the Tribunal accepted evidence to the effect that the governmental action at issue aggravated, but did not create, KGM's financial difficulties. In the absence of a definitive means of calculating the damage caused to Petrobart, the Tribunal assessed the damage on the basis of "probabilities and reasonable appreciation", ${ }^{67}$ awarding Petrobart 75 per cent of its claims against KGM.

- $\quad$ Cases pending

- Repsol YPF Ecuador S.A. v. Empresa Estatal Petroleos del Ecuador (Petroecuador) (ICSID Case No. ARB/01/10) Oil exploration contract; Annulment proceedings pending

- F-W Oil Interests, Inc. v. Republic of Trinidad \& Tobago (ICSID Case No. ARB/01/14); Oil and gas development contract, Decision pending

- M.C.I. Power Group, L.C. and New Turbine, Inc. v. Republic of Ecuador (ICSID Case No. $\mathrm{ARB} / 03 / 6)$ Electric power generation project, Decision pending

- Duke Energy International Peru Investments No. 1 Ltd v. Republic of Peru (ICSID Case No. ARB/03/28) Power generation project, Decision Pending

- Duke Energy Electroquil Partners and Electroquil S.A. v. Republic of Ecuador (ICSID Case No. ARB/04/19) Power generation facilities, Decision pending

- Alstom Power Italia SpA and Alstom SpA v. Republic of Mongolia (ICSID Case No. ARB/04/10) Thermal energy station project, Decision pending

- Togo Electricité v. Republic of Togo (ICSID Case No. CONC/05/1) Electricity concession, Tribunal recently constituted

- Noble Energy Inc. and Machala Power Cía. Ltd. v. Republic of Ecuador and Consejo Nacional de Electricidad (ICSID Case No. ARB/05/12) Electricity enterprise, Tribunal not yet constituted
64. At p. 74 .
65. At p. 75 .
66. Article 10(12) Energy Charter Treaty.
67. At p. 83. 
- Ioannis Kardossopoulos v. Georgia (ICSID Case No. ARB/05/18) Oil and gas distribution enterprise, Tribunal not yet constituted

\section{5)}

The Argentine cases

94. In 1989 Argentina embarked on a far reaching programme of economic reform. As part of this programme, many previously State-owned companies were privatized in particular in important industry sectors and public utilities. Legislation enacted to effectuate this privatization programme, along with individual contracts, created dollar-obligations on Argentina. In late 1999, however, Argentina began to experience major economic difficulties and in response Argentina took a series of legislative measures intended to alleviate these economic difficulties. These measures marked the end of the Argentinean peso being pegged to the US dollar. In particular, "emergency legislation" began the "pessification" of Argentina's contractual obligations by "re-dominating rates and tariffs into pesos and extinguishing the right of the licensees in the regulated public sector to link tariffs to US price indices". 68

95. Currently, ICSID has registered 33 arbitrations against Argentina in which the above described facts form the basis of the claim. It is unknown whether or how many other arbitrations have been instituted beyond the ICSID context. The claims currently pending before ICSID can be grouped into the following categories:

Oil and gas (exploration, power generation, distribution and transportation):

- $\quad$ CMS Gas Transmission Company v. Argentine Republic (ICSID Case No. ARB/01/8) Gas transmission enterprise

- Enron Corporation and Ponderosa Assets, L.P. v. Argentine Republic (ICSID Case No. ARB/01/3) Natural gas transportation company

- LG\&E Energy Corp., LG\&E Capital Corp. and LG\&E International Inc. v. Argentine Republic (ICSID Case No. ARB/02/1) Gas distribution enterprise

- Sempra Energy International v. Argentine Republic (ICSID Case No. ARB/02/16) Gas supply and distribution enterprise

- Camuzzi International S.A. v. Argentine Republic (ICSID Case No. ARB/03/2) Gas supply and distribution enterprise

- Pan American Energy LLC and BP Argentina Exploration Company v. Argentine Republic (ICSID Case No. ARB/03/13) Hydrocarbon and electricity concessions

- El Paso Energy International Company v. Argentine Republic (ICSID Case No. ARB/03/15) Hydrocarbon and electricity concessions

- Total S.A. v. Argentine Republic (ICSID Case No. ARB/04/1) Gas production and distribution/power generation project

- BP America Production Company and others v. Argentine Republic (ICSID Case No. $\mathrm{ARB} / 04 / 8)$ Hydrocarbon concession and electricity generation project

68. CMS Gas Transmission Company v. Argentine Republic (Case No. ARB/01/8). 
- Wintershall Aktiengesellschaft v. Argentine Republic (ICSID Case No. ARB/04/14) Gas and oil production

- Mobil Exploration and Development Inc. Suc. Argentina and Mobil Argentina S.A. v. Argentine Republic (ICSID Case No. ARB/04/16) Gas production concessions

Electricity generation and distribution:

- Camuzzi International S.A. v. Argentine Republic (ICSID Case No. ARB/03/7) Electricity distribution and transportation enterprise

- Enersis, S.A. and others v. Argentine Republic (ICSID Case No. ARB/03/21) Electricity distribution enterprise

- Electricidad Argentina S.A. and EDF International S.A. v. Argentine Republic (ICSID Case No. ARB/03/22) Electricity distribution enterprise

- EDF International S.A., SAUR International S.A. and Léon Participaciones Argentinas S.A. v. Argentine Republic (ICSID Case No. ARB/03/23) Electricity distribution enterprise

- Compañía General de Electricidad S.A. and CGE Argentina S.A. v. Argentine Republic (ICSID Case No. ARB/05/2) Electricity distribution concessions

Water and sewerage concessions:

- Azurix Corp. v. Argentine Republic (ICSID Case No. ARB/01/12)

- Aguas Provinciales de Santa Fe, S.A., Suez, Sociedad General de Aguas de Barcelona, S.A. and Interagua Servicios Integrales de Agua, S.A. v. Argentine Republic (ICSID Case No. ARB/03/17) Water services concession

- Aguas Cordobesas, S.A., Suez, and Sociedad General de Aguas de Barcelona, S.A. v. Argentine Republic (ICSID Case No. ARB/03/18) Water services concession

- Aguas Argentinas, S.A., Suez, Sociedad General de Aguas de Barcelona, S.A. and Vivendi Universal, S.A. v. Argentine Republic (ICSID Case No. ARB/03/19) Water services concession

- Azurix Corp. v. Argentine Republic (ICSID Case No. ARB/03/30) Water and sewer services concession agreement

- SAUR International v. Argentine Republic (ICSID Case No. ARB/04/4) Water and sewer services concession agreement

Telecommunications:

- Telefónica S.A. v. Argentine Republic (ICSID Case No. ARB/03/20) Telecommunications enterprise

- France Telecom S.A. v. Argentine Republic (ICSID Case No. ARB/04/18) Telecommunications concession

- TSA Spectrum de Argentina, S.A. v. Argentine Republic (ICSID Case No. ARB/05/5) Telecommunications concession 
Other

- Siemens A.G. v. Argentine Republic (ICSID Case No. ARB/02/8) Informatics services contract

- Metalpar S.A. and Buen Aire S.A. v. Argentine Republic (ICSID Case No. ARB/03/5) Motor vehicle enterprise

- Continental Casualty Company v. Argentine Republic (ICSID Case No. ARB/03/9) Insurance company

- Unisys Corporation v. Argentine Republic (ICSID Case No. ARB/03/27) Information storage and management project

- $\quad$ CIT Group Inc. v. Argentine Republic (ICSID Case No. ARB/04/9) Leasing enterprise

- RGA Reinsurance Company v. Argentine Republic (ICSID Case No. ARB/04/20) Financial reinsurance services

- DaimlerChrysler Services AG v. Argentine Republic (ICSID Case No. ARB/05/1) Leasing and financial services

- Asset Recovery Trust S.A. v. Argentine Republic (ICSID Case No. ARB/05/11) Collection contract

Only one Final Award has been handed down in relation to these cases. In CMS Gas Transmission Company v. The Argentine Republic ${ }^{69}$ Argentina was held liable for damage suffered by the claimant in respect of its $29 \%$ share ownership in a domestic enterprise involved in natural gas transportation. Argentina was held responsible for both breaches of its contractual obligations and treaty obligations in respect of the "emergency measures" taken to cure the financial crisis.

96. The factual background of the case is the economic reform programme commenced in 1989 which had as one of its objectives attraction of foreign direct investment. In order to achieve this goal, the Argentine government began privatising its State-owned companies, enacted the Convertibility Law 1991 which pegged the peso to the US dollar and undertook other stabilisation measures. Certain other measures specific to the gas industry were also undertaken through legislative acts, in particular tariffs were to be calculated in US dollars and converted to pesos at the exchange rate at the time of billing. Additionally, these tariffs were to be adjusted semi-annually in accordance the US Producer Price Index. Within this legal framework and as part of the privatisation scheme CMS acquired a $29.42 \%$ share ownership in the domestic entity Tranportadora de Gas del Norte (TGN) which had been granted a 35 year gas transportation licence.

97. In the late 1990's, at the beginning of the financial crisis, the government of Argentina entered into two separate agreements with gas transportation and distribution enterprises which temporarily suspended the tariff adjustment but which also foresaw recoupement at the end of the period of suspension. By late 2001, however, it became apparent that these corrective measures were not sufficient to prevent a worsening of the financial crisis and in January 2002 Argentina enacted the Emergency Law of 2002. The law purported to reform the foreign exchange system through implementation of four main measures: (i) the Convertibility Law 1991 was abolished and the peso devalued; (ii) the right of licensees

69. CMS Gas Transmission Company v. Argentine Republic Award 12 May 2005 (ICSID Case No. ARB/01/8). 
of public utilities to have the tariffs adjusted according to the US PPI was terminated; (iii) the right to calculation of tariffs in US dollars was terminated and; (iv) a process of renegotiation of licences was envisaged. While renegotiation of licences was successful with regard to certain public utilities, renegotiation of gas transportation and distribution licences was not successfully completed before expiration of the specially created Renegotiation Commission's mandate. In July 2001, ICSID registered CMS' claim alleging breaches of the US-Argentina Bilateral Investment Treaty.

98. In its Decision on Jurisdiction of July 17, 2003 the Tribunal asserted jurisdiction to hear CMS claims. Three major points were elaborated upon in this Decision. First, while the Tribunal recognised it did not have jurisdiction under the ICSID Convention over questions of general economic policy, it did hold that its jurisdiction could be established "if those general measures are adopted in violation of specific commitments given to the investor in treaties, legislation or contracts. What is brought under the jurisdiction of the Centre is not the general measure in themselves but the extent to which they may violate those specific commitments." ${ }^{, 70}$ Secondly, and importantly, the Tribunal rejected Argentina's argument that CMS was not a holder of the rights breach of which formed the basis of the claim. In this respect the Tribunal considered that international law had evolved in such a manner as to allow shareholder claims independently of those of the corporate entity, irrespective of whether such shareholding was a minority or non-controlling shareholding. Further, the Tribunal concluded that the direct right of shareholders to raise a treaty claim was contained in the relevant BIT.

99. The third major point in the Decision related to assertions raised by Argentina regarded potential consequences of the Tribunal assuming jurisdiction over the claim. These consequences pertained to: (i) the risk of TGN successfully renegotiating its licence while separately an ICSID Tribunal comes to a conflicting conclusion; (ii) potential discrimination between domestic and foreign investors in terms of access to judicial remedies insofar as domestic investors do not have recourse to international arbitration; (iii) the risk of a multiplicity of claims raised by different shareholders of different nationalities and pertaining to different BITs and; (iv) awarding damages to CMS would incorrectly presume that had TGN received compensation those benefits would have flowed through to its shareholders. The Tribunal rejected all of these assumed consequences, stating:

The Tribunal notes in respect that the Centre has made every effort possible to avoid a multiplicity of tribunals and jurisdictions, but that it's not possible to foreclose rights that different investors might have under different arrangements. The Tribunal also notes that, while it might be desirable to recognise similar rights to domestic and foreign investors this is seldom possible in the present state of international law in this field. Finally, it is not for the Tribunal to rule on the perspectives of the negotiation process or on what TGN might do in respect of its shareholders, as these are matters between Argentina and TGN or TGN and its shareholders. ${ }^{71}$

100. In its Award on the merits of 12 May, 2005 the Tribunal held Argentina liable under the USArgentina BIT for breach of the fair and equitable standard of treatment and breach of contractual commitments contrary to the umbrella clause. On the other hand, the Tribunal rejected the claim of expropriation as the Claimant retained ownership, management and control of its shares. In reaching its

\footnotetext{
70. CMS Gas Transmission Company v Argentina (ICSID Case No Arb/01/8), Decision on Jurisdiction 17 July, 2003 at para. 27.

71. Decision on Jurisdiction at para. 86.
} 
conclusions, the Tribunal first determined that the Claimant had a right under the legal framework of the investment to a tariff calculated in US dollars and to semi-annual adjustment of these tariffs according to the US PPI. Argentina was also held liable for breach of contractual obligations in violation of the Umbrella Clause contained in the BIT.

101. The Tribunal then considered whether breach of these rights was nevertheless excusable under domestic law principles of contract but concluded that the legal ingredients necessary to excuse breach of contract were not met. In this respect the Tribunal did consider the impact of the crisis on the contractual relationship existing between the government and the investor. "The fact is that the Claimant cannot ask to be entirely beyond the reach of the abnormal conditions prompted by the crisis, as this would be unrealistic. However, at the same time, it would be wholly unjustifiable that the Claimant be overburdened with all the costs of the crisis". ${ }^{72}$ Nor did the Tribunal accept that the defence of necessity under customary international law was established. The Tribunal concluded that while the financial crisis was severe it was not sufficiently serious to warrant application of the defence of necessity under international law nor dd the Tribunal consider that the emergency measures were the only means by which the crisis situation could be resolved.

102. Furthermore, the BIT contained an Emergency Clause in its Article XI which precludes wrongfulness in certain prescribed emergency situations. As such, the Tribunal was tasked with considering whether the prerequisites for its application were established in the context of financial crisis and thus precluded wrongfulness under the Treaty. Again, the Tribunal stated its conclusion that "the Tribunal is convinced that the Argentine crisis was severe but did not result in total economic and social collapse". ${ }^{73}$ As such, the Tribunal held that the Treaty protections remained enforceable against the Respondent. Moreover, based on other treaty practice, the Tribunal was of the opinion that the Emergency Clause was not self-judging and consequently invocation of this Article would necessitate a substantive review of the legitimacy of the actions taken by a Tribunal. Lastly, the Award stated that the question of precluding wrongfulness under the rules of state responsibility was without prejudice to the question of compensation. The remedy awarded to the Claimant, using the discounted cash flow method of valuation, was damages to the sum of US\$133.2 million plus interest and an order on Argentina to purchase the Claimant's shares within one year for the additional amount of US\$2 148100.

103. Argentina has, however, moved to annul the Award; at present the annulment committee has not yet been constituted. ${ }^{74}$ The request for annulment takes issue with each of these findings by the Tribunal, arguing that the Tribunal manifestly exceeded its powers or failed to state the reasons for its conclusions. The request also seeks to reinforce the severity of the financial crisis, the diminution of which impacted on the decision of the Tribunal in its Award.

Enron Corporation and Ponderosa Assets, L.P. v The Argentine Republic, Decision on Jurisdiction and Decision on Jurisdiction (Ancillary Claim) (ICSID Case No ARB/01/3). The first claim raised by Enron relates to tax duties imposed by several provinces of Argentina. The Claimant has alleged that these tax assessments are illegal under domestic law and are measures tantamount to expropriation, in violation of international law and the US-Argentina BIT. The Ancillary Claim relates to the termination of the tariffs calculated in US dollars and termination of the tariff adjustment

\footnotetext{
72. $\quad$ Award at para. 244.

73. Award at para. 355.

74. Request registered September 27 2005; see http://www.worldbank.org/icsid/cases/pending.htm
} 
mechanism established by the legal framework implemented by Argentina during the early 1990s. The reasons given in the Decisions for asserting jurisdiction to hear the disputes are largely similar to those expounded in the CMS arbitration.

OPIC Decision: Expropriation claim of Ponderosa Assets, L.P. Argentina - Contract of Insurance No. D733. OPIC has awarded at least one insurance claim in respect of investments made in Argentina and the subsequent Emergency measures.

104. Like the CMS arbitration, the Ponderosa claim relates to a domestic gas transportation enterprise (TGS) in which the claimant had a share ownership and has as the source of the claim the same factual background as the CMS claim. Ponderosa's involvement in this enterprise began in 1998 after acquiring Enron's 35\% ownership in TGS; at this time, and with OPIC's consent, Enron's OPIC insurance contract was also assigned to Ponderosa.

105. Unlike the CMS arbitration, however, the OPIC Tribunal considered that the acts of the government of Argentina were expropriatory in nature. The Tribunal did opine that the extinguishing of the economic value of an investment may amount to expropriation under modern conceptions of international law, however, the Tribunal did not consider it necessary to determine definitively whether such was the case in the present instance. Rather, the Tribunal founded its finding of expropriation on the basis of repudiation of its contractual undertakings by the government of Argentina. In this respect, the Tribunal considered that the Licence properly constituted a contract and that this contract was entered into with foreign nationals insofar as TGS was entirely owned by foreign nationals. This latter point was reinforced by reference to ICSID Tribunal Decision on Jurisdiction in a claim raised by Enron and Ponderosa $^{75}$ and the above mentioned CMS claim in which the direct right of action of shareholders was recognized; as TGS would be considered a foreign national for the purposes of a BIT claim, the Tribunal considered it could "also be considered a foreign national party to a contract under international law principles". ${ }^{76}$

106. A further issue to consider was whether Argentina had repudiated the Licence, the Tribunal stated: "The GOA has not disclaimed liability. However, GOA has materially changed the terms of the contract unilaterally, which amounts to the same thing. OPIC finds that this unilateral and material modification of the Licence constitutes a repudiation by FOA of its obligations under the Licence". ${ }^{77}$ The Emergency Law which terminated the right of the claimant to tariffs calculated in US dollars and tariff adjustments according to the US PPI was thus considered an abrogation of Argentina's obligations under the Licence. On this factual basis and theories of international law which argue that contractual breaches can amount to expropriation, the Tribunal considered Argentina to have acted in breach of international law. Further, doctrine provides that a State is not internationally responsible for repudiation of a contract where it is acting in a commercial capacity and as a private contract might. However, the Tribunal considered the measures in question were non-commercial in nature, more specifically Argentina was considered to be acting "for public policy reasons, specifically to curb the risk of inflation and devaluation and to control the flight of foreign exchange from Argentina."

75. Enron Corporation and Ponderosa Assets, L.P. v Argentine Republic (ICSID Case No ARB/01/3) Decision on Jurisdiction of August 2, 2004.

76. $\quad$ OPIC Award regarding Ponderosa Assets of 2 August, 2005 at p. 8.

77. $\quad$ Ibid at p. 8 . 
107. The Tribunal continued "While the contractual obligation could not prevent the government from carrying out sovereign acts, it does require that the government answer in damages for its conduct'. ${ }^{78}$ The Tribunal considered the effect of the Emergency measures was to completely extinguish the economic value of Ponderosa's investment. As such, OPIC awarded compensation to the full amount of the active amount of its insurance coverage, US\$50 million.

Gas Natural SDG, S.A.v The Argentine Republic, Decision on Jurisdiction of June 17, 2005 (ICSID Case No ARB/03/10). The same fact paradigm also led to a claim being raised by Gas Natural under the Spain-Argentina BIT.

108. Gas Natural, an enterprise incorporated under the laws of Spain, formed part of a consortium which participated in the Argentinean privatisation scheme through purchase of a $70 \%$ interest in BAN S.A., an Argentinean enterprise involved in production and distribution of natural gas. A special purpose vehicle was incorporated under the laws of Argentina for the purpose of holding these shares. Through subsequent restructuring of the shareholdings, the holding company held $51 \%$ of the shares in BAN S.A. and Gas Natural held a further 19\% of BAN S.A. through a subsidiary company.

109. In its claim, Gas Natural asserted its total shareholding in BAN S.A. stood at $50.4 \%$. Gas Natural's claim asserted violations of the Spain-Argentina BIT by reason of expropriation or measures tantamount to expropriation and breach of fair and equitable treatment. The factual underpinnings for these allegations are the termination of the US-dollar based tariff regime, termination of the ariff adjustment mechanism according to the US PPI and the negative impact of the measures on BAN S.A.'s ability to repay its dollar denominated loans while its returns were in depreciated pesos. These measures were alleged to have severely depreciated the value of the Claimant's investment.

110. Like in $C M S$, the Tribunal's Decision on Jurisdiction concluded that under the relevant BIT the Claimant benefited from a direct right of action in respect of measures affecting the value of its shareholding. The Tribunal similarly distinguished between measures of general economic policy, which fall outwith the jurisdiction of the Centre, and the question of whether those measures violate specific commitments given to an investor. The Tribunal also accepted operation of the most favoured nation clause to permit the Claimant to benefit from more favourable dispute resolution provisions contained in the US-Argentina BIT and thus avoid recourse to national courts as a pre-condition to jurisdiction. Subsequent to this Decision, on 11 November 2005, arbitral proceedings were suspended at the request of the parties.

Camuzzi International S.A. v The Argentine Republic, Decision on Jurisdiction (ICSID Case No $A R B / 03 / 2)$ and Sempra Energy International $v$ The Argentine Republic, Decision on Jurisdiction (ICSID Case No. ARB/02/16). These two cases have been subjected to de facto consolidation and the Decisions on Jurisdiction, while delivered separately, are substantially identical.

111. The Camuzzi claim is based on the 1990 BIT concluded between Argentina and the BelgoLuxembourg Economic Unit; the Sempra claim is raised under the 1991 Argentina-US BIT. The business activities of both Claimants in Argentina arose in the context of the latter's privatisation of the gas sector. The Tribunal described the nature of their involvement in Argentina as follows:

78.

Ibid at p.11-12. 
Camuzzi owns $56.91 \%$ of the share capital of Sodigas Sur S.A. ("Sodigas Sur") and Sodigas Pampeana S.A. ("Sodigas Pampeana"). In its turn, Sempra...owns 43.09\% of Sodigas Sur and Sodigas Pampeana. The latter two Argentine companies, in turn, hold 90\% and $86.09 \%$, respectively, of the shares in Camuzzi Gas del Sur S.A. ("CGS") and Camuzzi Gas Pampeana ("CGP"), each of which, in its capacity as a "Licensee," is a natural gas distribution company. Both CGS and CGP each hold a license granted by the Argentine Republic to both supply and distribute natural gas in seven provinces in that country. ${ }^{79}$

112. The underlying facts of the disputes are substantially identical to those underpinning the $C M S$ and Gas Natural disputes and are alleged to have violated certain investment protection provisions in the relevant BITs. The Tribunal has assumed jurisdiction to hear the claims; a decision on the merits is pending.

Discontinued or settled cases. Four arbitrations raised against Argentina have been discontinued. The Argentinean authorities have pre-conditioned re-negotiation of contracts and tariff hikes on withdrawal of arbitral claims. Pioneer Natural Resources, ${ }^{80} \boldsymbol{A E S}^{81}$ and Gas Natural ${ }^{82}$ agreed to drop their claims in early 2005 and are in the process of renegotiating their contracts. ${ }^{83}$ Mobil Argentina discontinued its case against Argentina in July $1999^{84}$ but has since raised a second claim in conjunction with another party. ${ }^{85}$

79. Camuzzi International S.A. v The Argentine Republic, Decision on Jurisdiction 11 May 2005 (ICSID Case No. ARB/03/2) para. 9.

80. Pioneer Natural Resources company, Pioneer Natural Resources (Argentina) S.A. and Pioneer Natural Resources (Tierra del Fuego) S.A. $v$ The Argentine Republic (ICSID Case No ARB/03/12) relating to hydrocarbon and electricity concessions. Case discontinued June 2005.

81. AES Corporation v. Argentine Republic (Case No. ARB/02/17) relating to dectricity generation and distribution operations. Case reported to have been dropped in April 2005 (see Business News Americas, AES drops ICSID Claim, Edelap Talks Advance, April 15, 2005).

82. Gas Natural SDG, S.A. v. Argentine Republic (Case No. ARB/03/10) relating to gas supply and distribution enterprise. Proceedings suspended on 11 November, 2005.

83. Business News Americas, AES drops ICSID Claim, Edelap Talks Advance, April 15, 2005 ; US Oil Co. Pioneer Withdraws Lawsuit Against Argentine Government, AFX News 30 March, 2005; Pioneer Natural Resources Drops Argentine Arbitration Claim, World Markets Research 31 March, 2005.

84. Mobil Argentina S.A. v Argentine Republic (ICSID Case No. ARB/99/1).

85. Mobil Exploration and Development Inc. Suc. Argentina and Mobil Argentina S.A. v. Argentine Republic (ICSID Case No. ARB/04/16). 


\section{Construction contracts in infrastructure projects}

Salini Costruttori S.p.A. and Italstrade S.p.A. v Kingdom of Morocco, Decision on Jurisdiction 23 July 2001 (ICSID Case No. ARB/00/4). This case concerns a construction contract entered into between the parties and final payment due there under.

113. The two claimant parties to this arbitration jointly won an international tender to construct a section of highway joining Rabat to Fès. The works were completed in October 1998, four months outside the deadline stipulated in the contract. A dispute arose between the parties in relation to the final amounts payable under the contract. A draft final account was sent to the two claimant parties who signed it with reservations. These reservations were cited as: "technical reservations, exceptionally bad weather, project upheaval, modifications concerning the dimensions of the work, extension of contractual time limits, financial burdens, unforeseeable fluctuations of the value of the Yen." The Tribunal has held it has jurisdiction over the claims except insofar as they relate to breach of contract where such breaches do not also constitute treaty violations. A decision on the merits is pending.

Consortium RFCC v Morocco, Award 22 December 2003 (ICSID Case No. ARB/00/6). This case concerns a construction contract entered into between the parties and final payment due there under. The claim was rejected as the Tribunal considered the dispute to be of a purely contractual nature.

114. In 1995, a consortium constituted under the laws of Italy entered into a contract with the Société Nationale des Autoroutes du Maroc (ADM) for the construction of a section of the Rabat-Fès highway. The construction suffered several delays and in September 1997 the parties entered into an agreement under which the date for completion for part of the construction works would be suspended to a later date. Nevertheless, handover of the site did not take place until after the agreed deadline.

115. The dispute between the parties concerned final payment under the contract; negotiations to settle the dispute failed and the claimant proceeded to arbitration. The claimant alleged, inter alia, (i) changes in the amount and type of work required for the project increased its costs; (ii) construction delays were, in part, attributable to unforeseen and exceptionally bad weather conditions; (iii) delays in construction were also attributable to failures of ADM under the contract such as late handover of the construction site; (iv) these delays increased the costs of the claimant through costs incurred during inactivity and additional costs incurred to make up for lost time; (v) the nature of the delays were such as to entitle the claimant to an extension under the contract which ADM denied and; (vi) ADM imposed a penalty for late completion of the construction works and did not compensate the claimant for additional costs incurred under the contract.

116. Morocco, for its part, argued that the actions of ADM were not attributable to the government of Morocco or, in the alternative, that ADM had not acted in breach of its contractual obligations. In its Decision on Jurisdiction of the 16 July 2001 the Tribunal held it had jurisdiction under the Italy-Morocco BIT to hear claims for breaches of Treaty protections, however, under the terms of the Treay, the Tribunal did not have jurisdiction to hear claims of a purely contractual nature. As such, in its examination of the merits, the Tribunal concluded that the allegations of the claimant could only be upheld insofar as the alleged contractual breaches by the ADM were attributable to the State and insofar as these alleged breaches amounted to breach of BIT protections. On this latter point, the claimant's allegations of breach of treaty failed. 
117. The Tribunal considered each point raised by the claimant remained within the realm of contractual dispute between the parties and did not rise to the level of an international delict. "En réalité, le désaccord des parties, en fait et en droit, ne dépasse pas le cadre normal d'un litige purement contractuel entre le maitre de l'ouvrage et l'entrepreneur". ${ }^{86}$ The Tribunal did not pronounce on liability of either party under the contract and considered its conclusions valid regardless of any potential breach of contractual obligations by either party. The Decision of the Tribunal has been subjected to annulment proceedings, a decision of the annulment committee is currently pending.

Consorzio Groupement L.E.S.I.-DIPENTA v Algeria, Decision of 10 January, 2005 (ICSID Case No ARB/03/08). This case relates to termination of a construction contract; the Tribunal, however, refused jurisdiction as there was no identity between the parties to the contract and the parties named in the arbitral claim.

118. In September 1992, Algeria, acting through a state agency, "Agence nationale des barrages" (ANB) opened for tender construction of the Koudiat Acerdoune barrage intended to supply drinkable water to surrounding towns. In November of the same year the tender of the two companies party to the consortium who raised the present claim was accepted and in December 1993 a contract was entered into with ANB for construction of the barrage. On the same day as conclusion of the contract, the consortium was formally entered into under the laws of Italy. Construction began but fell behind schedule and ultimately in 1997 was suspended by order of the ANB. The claimants alleged, inter alia, works under the contract were hampered by security concerns and the contract was terminated because of changes in the design and construction of the dam. Algeria, on the other hand, argued termination of the contract was not a voluntary act of the State but rather financing for the project from the African Bank for Development conditioned its financing on re-opening the project to tender to take into account the design changes. The Tribunal, however, found it did not have jurisdiction to hear the claims insofar as the contract was signed by the two claimant companies separately and individually while the arbitral claim was raised by a different legal person, the consortium. As such, the consortium was held to lack standing to invoke arbitral jurisdic tion. The two companies have since registered ICSID arbitrations in their own names. ${ }^{87}$

Salini Costruttori S.p.A. and Italstrade S.p.A. $v$ the Hashemite Kingdom of Jordan, Decision on Jurisdiction 9 Novermber 2004 (ICSID Case No. ARB/02/13). The origin of th is arbitration is a dispute between the parties to a construction contract as to the final payments due under that contract.

119. In May 1993 the companies party to this arbitration were awarded a contract for the construction of the Kamareh Dam Project; contracts were entered into with the Ministry of Water and Irrigation-Jordan Valley Authority. The works were completed in October 1997 and in April 1999 Salini issued a draft final statement for outstanding payment for a sum of approximately US\$28 million. The Respondent, however, calculated the outstanding payment to be US\$49 140. In an attempt to reach agreement on the outstanding sum, the parties entered into a series of meetings including, notably, a meeting between the Italian Prime Minister and Minister for Foreign Trade and the Jordanian Prime Minister and Minister of Water and Irrigation. In its Award of 31 January 2005, the Tribunal dismissed

86. At para. 104.

87. Reported Petersen, Algerian dam construction case lands back on ICSID docket, INVEST-SD: Investment Law and Policy News Bulletin, May 5 2005; LESI, S.p.A. and Astaldi, S.p.A. v. Algeria (ICSID Case No. ARB/05/3). 
all claims against the Kingdom of Jordon on the grounds that the Claimant had not established the existence of an arbitration agreement between the parties.

Impregilo S.p.A. v Islamic Republic of Pakistan, Decision on Jurisdiction, 22 April 2005 (ICSID Case No. ARB/03/3). While a decision on the merits is still pending, an ICSID Tribunal has assumed jurisdiction in relation to the State's conduct in relation to a construction contract entered into between the Claimant and a State Agency. The Claimant had alleged breach of contract and breach of investment protections, however, the Tribunal found its jurisdiction was limited only to the latter claims.

120. The dispute in this case arose in relation to construction of the Ghazi Barotha Hydropower Project in Pakistan. The Claimant formed part of a consortium (GBC) which entered into a contract with the Water and Power Development Authority of Pakistan (WAPDA) for construction of a barrage and ancillary structures. Performance under the contract was to be controlled by an Engineer. Construction began in 1996 and was scheduled for completion in 2000. Completion of these works, however, fell behind schedule.

"The claimant contends that the timely performance of the preliminary tasks under the first contract was impeded by delay in the Engineer's issuance of detailed instructions. In addition, the Engineer increased the amount of foundation work to be carried out, and the preliminary work led to the discovery of unforeseen geological conditions. The construction of the main barrage was also delayed by the Engineer's failure to give timely approvals and issue instructions for the work. Furthermore, the instructions were inadequate in detail and required work more complex than had been shown in the tender drawings. In addition, WAPDA failed to deliver to GBC items of equipment it had to supply, or delivered them many months later than scheduled. Further, the Claimant contends that the implementation of the second contract was hampered by WAPDA's failure to turn over the land necessary to carry out the work in a proper manner. Moreover, acts and omissions of WAPDA and the Engineer significantly impeded GBC's ability to proceed according to schedule. Sections of the concrete lining for the channel, when completed, were damaged due to the Engineer's design defects. Design details for the construction of bridges and other ancillary structures were issued late. Moreover, GBC was required to build 50\% more concrete structures than required by the tender documents."

121. Construction was also further delayed by the events of 11 September 2001. In view of security concerns, foreign personnel were ordered by their governments to return to their home countries. The Engineer and WAPDA refused to grant a suspension of work order and in December 2001 WAPDA sought damages from the consortium for its failure to meet the work schedule. A negotiated agreement between the parties settled the terms for resumption of works and extended the deadline for completion of construction to July 2003. The consortium would in turn relinquish claims arising from this period of time. This agreement was without prejudice to any claims which arose prior to 11 September 2001. Construction was "substantially completed" ${ }^{88}$ in January 2003 however a formal Taking-Over Certificate was not issued by WAPDA. In September 2003, the claimant alleges WAPDA wrongfully began withholding monthly payments owed under the contract. The claimant lodged a request for ICSID arbitration in January 2003 alleging breach of contract and breach of the Italy-Pakistan BIT 1997.

88.

At para. 52. 
122. The Tribunal was tasked with, inter alia, determining attribution of WAPDA's conduct to the State under international principles of State Responsibility. Pakistan could only be liable for WAPDA's conduct if its conduct could be attributed to the State. The Tribunal, however, considered that the instruments giving legal life to WAPDA and its methods of operation were of such a nature as to qualify WAPDA as a separate corporate person, distinct and independent of the State.

Given that the contracts at issue were concluded between the Claimant and WAPDA, and not between the Claimant and Pakistan; that under the law of Pakistan, which governs both the contracts and the status and capacity of WAPDA for the purposes of the Contracts, WAPDA is a legal entity distinct from the State and Pakistan; and given that Article 9 of the BIT does not cover breaches of contracts concluded by such an entity, it must follow that this Tribunal has no jurisdiction under the BIT to entertain Impregilo's claims based on alleged breaches of the contract. ${ }^{89}$

123. On the other hand, certain of Impregilo's claims related to the conduct of Pakistan itself. In particular, the claimant alleged breach of fair and equitable treatment and expropriation contrary to the provisions of the BIT. In respect of both these provisions, however, the Tribunal rejected claims raised in respect of unforeseen geological conditions. In the view of the Tribunal, these treaty protections are only applicable insofar as the actions complained of result of the exercise of the sovereign power of the State. With regards to the unforeseen geological conditions, the Tribunal stated: "These are matters that concern the implementation of the Contracts, and do not involve any issue beyond the application of a contract, and the conduct of contracting parties. In particular, the matter does not concern any exercise of puissance publique by the State". ${ }^{90}$ On the other hand, the other treaty based claims raised by the claimant were allowed by the Tribunal and will be considered at the merits stage of proceedings.

124. Applicability of the BIT was, however, limited in two further respects. First, as the claimant was involved in the construction project as a member of the consortium, the claims have been allowed only insofar as they concern the claimant's own alleged losses and not those of the consortium as a whole. While the claimant initially requested damages of approximately US $\$ 450$ million, this amount will be limited to the claimant's proportionate participation in the consortium, i.e. 57.8\%. Second, as the BIT entered into force on 22 June 2001 and is consequently applicable only after that date, the Tribunal determined "the provisions of the BIT do not bind Pakistan in relation to any act that took place, or any situation that ceased to exist, before 22 June 2001 and the jurisdiction of the Tribunal ratione temporis is limited accordingly". ${ }^{91}$
89. At para. 216.
90. At para. 268.
91. At para. 314 . 